\title{
Irradiation suppresses STAT3-mediated MCL1 expression to augment CD8+ T cells cytotoxicity against EGFR-positive lung cancer
}

\author{
Chun-I Wang \\ Chang Gung University \\ Yi-Fang Chang \\ Mackay Memorial Hospital \\ Zong-Lin Sie \\ Chang Gung University \\ Ai-Sheng Ho \\ Cheng Hsin General Hospital \\ Chun-Chia Cheng ( $\square$ cccheng.biocompare@gmail.com ) \\ Chang Gung University https://orcid.org/0000-0002-6455-1798
}

\section{Research}

Keywords: Non-small-cell lung cancer, STAT1, STAT3, PD-L1, MCL1, CD8+ T cells, irradiation, radiotherapy

Posted Date: May 11th, 2021

DOI: https://doi.org/10.21203/rs.3.rs-497648/v1

License: (c) (1) This work is licensed under a Creative Commons Attribution 4.0 International License. Read Full License 


\section{Abstract \\ Background}

Tumor cells progress to evade immunological attacks and prohibit activity of $\mathrm{CD} 8^{+} \mathrm{T}$ cells. Irradiation damages tumor cells and augments tumor immunotherapy in clinical application. However, the detail mechanism remains elusive. We aimed to uncover the mechanism of irradiation augmenting cytotoxic CD ${ }^{+}$ T cells to suppress tumor progression in non-small-cell lung cancer (NSCLC).

\section{Methods}

EGFR-positive NSCLC cell lines were co-cultured with isolated PBMCs from healthy volunteers, cell viability and apoptosis were measured. RNAseq was used to screen the IFNY-mediated gene expression in A549 cells. Irradiation was used to augment PBMCs-mediated anti-tumor effect and the irradiation effect to IFNYmediated gene expression was investigated using qPCR and Western blots.

\section{Results}

Co-culture of tumor cells stimulates increase of granzyme B and IFNy in CD8 ${ }^{+} \mathrm{T}$, but A549 exhibits resistance against $\mathrm{CD} 8^{+} \mathrm{T}$ cytotoxicity. Irradiation inhibits $\mathrm{A} 549$ proliferation and enhances apoptosis, augmenting PBMCs-mediated cytotoxicity against A549. IFNy simultaneously increased phosphorylation on STAT1 and STAT3 in EGFR-positive lung cancer, resulting in overexpression of PD-L1. In RNAseq analysis, MCL1 was identified and increased by IFNy-STAT3 axis in A549 cells, we found that irradiation specifically inhibits phosphorylation on STAT1 and STAT3 in IFNr-treated A549, resulting in reductions of PD-L1 and MCL1. Moreover, knockdowns of STAT3 and MCL1 increased PBMCs against irradiated A549 cells.

\section{Conclusion}

This study demonstrated that A549 expressed MCL1 against CD8 ${ }^{+} \mathrm{T}$ cell-mediated apoptosis. In addition, we found that irradiation suppressed STAT3 phosphorylation and IFNY-mediated PD-L1 and MCL1 expression, revealing a potential mechanism of irradiation augmenting immune surveillance.

\section{Background}

Lung cancer is the most common type and the leading cause of cancer-related deaths worldwide [7]. The most common type is non-small cell lung cancer (NSCLC) which comprises $80 \%$ of lung cancers [56]. Selection of treatment for NSCLC mainly depends on the diagnostic stage of this disease and patient's immune diversity. Basic treatments included surgical resection and radiotherapy (RT) that are often preferred and efficient for the patients with early-stage of NSCLC, whereas RT is used at least once in over $60 \%$ of lung cancer patients until cure or palliation of this disease [35]. Moreover, sequential chemotherapy with RT or concurrent chemoradiotherapy is also suggested for disease remission in patients with locally advanced 
stage of lung cancer [5]. It indicates that RT plays critical for NSCLC treatment, such as external beam radiation therapy and brachytherapy.

Personal medicine targeting specific gene characteristics currently applied in lung cancers, that results in better outcome for this disease [18]. The main characteristic of NSCLC is EGFR overexpression: targeted therapies against EGFR such as tyrosine kinases inhibitors (TKIs), including the first-generation TKIs gefitinib and erlotinib, the second-generation TKI afatinib for EGFR and HER2 blockades, and the third-generation TKI osimertinib for EGFR T790M mutation have been demonstrated to improve clinical progression-free survival (PFS) compared with the conventional chemotherapies in patients with advanced NSCLC [17, 21]. For tumor recurrence and resistance to TKIs, other treatments such as platinum-based chemotherapy combined with an agent directed to either ALK rearrangements or ROS1 rearrangements are recommended for patients with metastatic stage of NSCLC $[16,51]$.

Besides, immunotherapy reactivating $\mathrm{CD} 8^{+} \mathrm{T}$ cells such as anti-PD- 1 antibodies exhibits tumor therapeutic promise against NSCLC and results in $20 \%$ tumor remission in the patients fail to treatments of chemotherapies or targeted therapies $[28,52,55]$. To date, the monoclonal antibodies targeting PD- 1 and PDL1 interaction, pembrolizumab and nivolumab for PD-1 and atezolizumab for PD-L1, are approved by FDA for the treatment of metastatic NSCLC [34]. The immune surveillance is responsible for outside infections and currently found to potentially eradicate tumors: $C D 8^{+} T$ cells recognize tumor cells and secrete ganzymen $\mathrm{B}$ (GZMB) and perforin (Prf1) to elicit tumor cell apoptosis and death [14]. Immune checkpoints expressing in tumor cells, including PD-L1, galactine 9, HVEM, are able to exhaust CD8 ${ }^{+}$T cells and reduce CD $8^{+}$T-derived cytotoxicity $[1,43,53]$. In tumor microenvironment, IFNY is secreted by $T$ lymphocytes to reactivate macrophages and $\mathrm{CD}^{+} \mathrm{T}$ cells, but it also stimulates PD-L1 overexpression in tumor cells through JAKsSTAT1 signaling pathway [24]. Meanwhile, EGFR-STAT3 axis also mediates PD-L1 expression in lung cancer [12]. A case report has revealed a successful tumor therapy by Pembrolizumab immunotherapy in TKIs refractory NSCLC [57]. But EGFR-resistance and downstream signaling gene STAT3 activated by other stimulations contribute to cell proliferation, anti-apoptosis, and resistance to $\mathrm{CD} 8^{+} \mathrm{T}$ cells in EGFR-positive lung cancer $[46,61]$.

Irradiation (IR) causes tumor DNA damage and results in consequent tumor apoptosis. In IR treatment, the accumulation of cytosolic DNA activates cGAS-STING signaling pathway [42], inducing type I IFN secretion and potentially reactivates immune surveillance against tumors. According to the preclinical and early clinical data, it demonstrates that IR enhances expression of MHC class I [19] and secretion of cytokines such as type I IFN [39], resulting in increase of homing rate of immune cells to tumor microenvironment [22, 41]. Therefore, IR-mediated tumor therapies are considered for improving anti-tumor efficacy of clinical immunotherapies [27, 37, 50]. In addition, type I IFN is able to induce PD-L1 expression that PD-L1 expression detection plays a critical role for anti-PD-1 therapies $[2,15]$. Previous studies have demonstrated that low doses of fractionated IR significantly improves $\mathrm{CD} 8^{+} \mathrm{T}$ cell-mediated tumor remission in combination with anti-PD-1 or anti-PD-L1 therapies [15, 25, 26]. However, IFNY from T lymphocytes and type I IFN from IRtreated tumors are able to activate JAKs-STAT1 axis $[24,49]$, that induces expressions of not only PD-L1 but also cell proliferation and anti-apoptosis genes [31, 54]. Since a previous study has indicated that UV light down-regulates IFNY-mediated STAT1 phosphorylation [3], we, therefore, proposed a hypothesis that IR may 
augment $C D 8^{+} T$ cells-mediated cytotoxicity through blocking IFNs-mediated activations of JAKs-STATs to against immunotherapies-resistant EGFR-positive NSCLC.

\section{Materials And Methods}

\section{Healthy volunteers}

Clinical blood was acquired in Mackay Memorial Hospital, Taipei, Taiwan. The study protocol was approved by regulatory authorities and Institutional Review Boards in Mackay Memorial Hospital (20MMHIS018e). Signed and informed written consent were obtained from all participants, and all research was performed in accordance with the relevant guidelines and regulations.

\section{Cell culture}

All the lung cancer cell lines used in this study were free of mycoplasma and reauthenticated through short tandem repeat profiling (Applied Biosystems, Massachusetts, USA). A549, PC9, and H1650 were cultured in Dulbecco's Modified Eagle's Medium (DMEM). HCC827 was cultured in Roswell Park Memorial Institute (RPMI) 1640 medium. The tumor cells cultured in the medium were supplied with $10 \%$ fetal bovine serum (FBS) and $1 \%$ penicillin-streptomycin (P/S). All cells were incubated at $37^{\circ} \mathrm{C}$ with $5 \% \mathrm{CO}_{2}$.

\section{Cell viability}

The WST-1 assay (Sigma, Munich, Germany) was used to measure the cell viability according to the manufacturer's protocol. In brief, $1 \times 10^{3}$ cells were seeded in a 96-well plate, whereas 4-times repeat was necessary for measuring the cell viability in a time-dependent manner. For evaluating the cytotoxic effect of irradiation, A549, HCC827, PC9, and H1650 were exposed to 0, 10, 20 Gy of irradiation and incubated for $48 \mathrm{~h}$. For evaluating the cytotoxic effect of PBMC and CD8 ${ }^{+} \mathrm{T}$ cells, $1 \times 10^{5} \mathrm{PBMCs}$ or $1 \times 10^{4} \mathrm{CD} 8^{+} \mathrm{T}$ cells were cocultured with $1 \times 10^{3}$ A549, HCC827, PC9, and H1650 cells individually and incubated for $48 \mathrm{~h}$. The same methodology was also used to determine the cytotoxic effect of PBMCs against A549shSTAT1, A549shSTAT3, A549shMCL1, A549shPDL1 compared to A549shLuc.

\section{Flow cytometry}

The $2 \times 10^{5}$ trypsinized tumor cells were resuspended in $100 \mu \mathrm{L}$ of RPMI medium and incubated with fluorescent reagents (EGFR-FITC, PDL1-PE, CD133-PE, and CD44-PE antibodies, BioLegend, San Diego, CA, USA) for 30 mins at room temperature. The cells were consequently added with $900 \mu \mathrm{L}$ of PBS buffer containing $1 \%$ of FBS and analyzed using an FACSCalibur Attune NxT Flow Cytometer (Invitrogen, Waltham, Massachusetts, USA). A commercial kit containing Annexin V-FITC and Propidium lodide was used (Strong Biotech Corporation, Taiwan) to detect apoptosis in tumor cells treated by $0,10,20$ Gy of irradiation and cocultured with healthy PBMCs.

\section{Western blots}

The procedure of Western blots was described previously [10]. The specific antibodies against STAT1, pSTAT1(Tyr701), STAT3, pSTAT3(Tyr705), ERK, pERK, and GAPDH were purchased from Cell Signaling 
(Danvers, Massachusetts, USA).

\section{Quantitative polymerase chain reaction (qPCR)}

The procedures for mRNA extraction and complementary DNA preparation were the same as described previously [10,13]. Quantitative polymerase chain reaction (qPCR) was performed using an SYBR Green system (Applied Biosystems, Foster City, CA, USA) according to the manufacturer's instruction. The primers are shown in Table 1. 
Table 1

The primer sequence for $\mathrm{APCR}$

\begin{tabular}{|c|c|c|}
\hline Genes & Direction & Primer sequence \\
\hline \multirow[t]{2}{*}{ GAPDH } & Forward & GAGTCAACGGATTTGGTCGT \\
\hline & Reverse & TTGATTTTGGAGGGATCTCG \\
\hline \multirow[t]{2}{*}{$G Z M B$} & Forward & ACTGCAGCTGGAGAGAAAGG \\
\hline & Reverse & TTCGCACTTTCGATCTTCCT \\
\hline \multirow[t]{2}{*}{ CD274 (PD-L 1) } & Forward & GTACCTTGGCTTTGCCACAT \\
\hline & Reverse & CCAACACCACAAGGAGGAGT \\
\hline \multirow[t]{2}{*}{ TNFRSF14 (HVEM) } & Forward & CCACTGGGTATGGTGGTTTC \\
\hline & Reverse & TCACCTTCTGCCTCCTGTCT \\
\hline \multirow[t]{2}{*}{ LGALS9 (Galectin-9) } & Forward & СCTTTGACCTCTGCTTCCTG \\
\hline & Reverse & AAACAGACAGGCTGGGAGAA \\
\hline \multirow[t]{2}{*}{ STAT1 } & Forward & CCGTTTTCATGACCTCCTGT \\
\hline & Reverse & TGAATATTCCCCGACTGAGC \\
\hline \multirow[t]{2}{*}{ STAT2 } & Forward & GAGGCCTCAACTCAGACCAG \\
\hline & Reverse & GCGTCCATCATTCCAGAGAT \\
\hline \multirow[t]{2}{*}{ STAT3 } & Forward & TTTCACTTGGGTGGAGAAGG \\
\hline & Reverse & GCTACCTGGGTCAGCTTCAG \\
\hline \multirow[t]{2}{*}{ PSM88 } & Forward & CACGGGTAGTGGGAACACTT \\
\hline & Reverse & ТСАСССААССАТСТТССТТС \\
\hline \multirow[t]{2}{*}{ PSMB10 } & Forward & AATGTGGACGCATGTGTGAT \\
\hline & Reverse & TCCAGGGTTAGTGGCTTCAC \\
\hline \multirow[t]{2}{*}{ NFKB2 } & Forward & GAACAGCCTTGCATCTAGCC \\
\hline & Reverse & TCCGAGTCGCTATCAGAGGT \\
\hline \multirow[t]{2}{*}{ SOCS3 } & Forward & GCCACCTACTGAACССТССТ \\
\hline & Reverse & ACGGTCTTCCGACAGAGATG \\
\hline \multirow[t]{2}{*}{ UBE2L 6} & Forward & СААССТСССТАССАССТGАА \\
\hline & Reverse & GCAAGGCTTCCAGTTCTCAC \\
\hline \multirow[t]{2}{*}{ EFNA1 } & Forward & GGTGACTGTCAGTGGCAAAA \\
\hline & Reverse & AGTGGAAGGAGCAGCACAGT \\
\hline
\end{tabular}




\begin{tabular}{|lll|}
\hline Genes & Direction & Primer sequence \\
\hline PML & Forward & ACACAACGTGAGCTTCATGG \\
\hline & Reverse & AAGTGGGGTGGAGACTCCTT \\
\hline FCL1 & Forward & AGCTGCAGAAGCAGAAGGAG \\
\hline & Reverse & GGAGTTAGGGAGGGTGTGGT \\
\hline ISG15 & Forward & AGAAAGCTGCATCGAACCAT \\
\hline ChIP_STAT1/3_MCL1 & Forward & AAAAGGGCTCACAAATCAGGT \\
\hline & Reverse & CCAGCTCCTACTCCAGCAAC \\
\hline ChIP_STAT1/3_PD-L1 & Forward & ACTAGCATGGCTGAGACAGTGA \\
\hline & Reverse & CATACCTAGTAGAACCTGCCCTGT \\
\hline
\end{tabular}

\section{Gene knockdown}

Gene knockdown was conducted using a short-hairpin RNA (shRNA)-expression lentivirus system that contains the specific shRNA (The target sequences are shown in Table 2) in the pLK0.1-puro vector generated by $293 \mathrm{~T}$ cells. The plasmids were purchased from the National RNAi Core Facility of Academia Sinica, Taipei, Taiwan. The procedure was the same described in our previous study [13]. In brief, 293T cells (70\% confluence) cultured in DMEM culture medium were transfected with $4 \mu \mathrm{g}$ of pLKO. 1 vector, $1 \mu \mathrm{g}$ of the envelope plasmid pVSV-G, and $3.6 \mu \mathrm{g}$ of the packaging plasmid pCMV $\triangle \mathrm{R} 8.91$. The plasmids were preincubated with $6 \mu \mathrm{L}$ of JetPRIME (Polyplus-transfection, New York, NY, USA) for 20 min at room temperature and consequently added to $293 \mathrm{~T}$ cells. The cultured medium was substituted with a fresh culture medium after $24 \mathrm{~h}$ and further incubated for $48 \mathrm{~h}$. The virus solution was collected and stored at $-80^{\circ} \mathrm{C}$. A549 cells cultured in $80 \%$ confluence were infected with the prepared lentivirus for $24 \mathrm{~h}$. The cells were then changed with DMEM medium containing $4 \mu \mathrm{g} / \mathrm{mL}$ of puromycin, which harvested after obtaining stable cells.

Table 2

The target sequence of shRNA plasmids

\begin{tabular}{|lll|}
\hline Gene & Clone ID & Targeted sequence \\
\hline Luciferase & TRCN0000072249 & GCGGTTGCCAAGAGGTTCCAT \\
\hline STAT1 & TRCN0000004266 & CGACAGTATGATGAACACAGT \\
\hline STAT3 & TRCN0000020842 & CACAATCTACGAAGAATCAA. \\
\hline MCL1 & TRCN0000005515 & GCAGAAAGTATCACAGACGTT \\
\hline PDL1 & TRCN0000056914 & CGAATTACTGTGAAAGTCAAT \\
\hline
\end{tabular}




\section{Enzyme-linked immunosorbent assay (ELISA) for measurement of IFNY}

The Human IFNy PicoKine ELISA (Boster, Pleasanton, CA, USA) was used according to the manufacturer's protocol to determine IFNy concentration in the medium of HCC827- and A549-stimulated PBMCs. In brief, $2 \times 10^{5} \mathrm{HCC} 827$ and $\mathrm{A} 549$ cells were co-cultured with $2 \times 10^{6} \mathrm{PBMCs}$ at $37^{\circ} \mathrm{C}$ overnight. The culture medium was collected and clarified by 2000 rpm centrifugation for $10 \mathrm{~min}$ and each $100 \mu \mathrm{l}$ of the supernatant medium was added to pre-coated anti-IFNy antibodies in a 96-well microplate. The consequent steps, including washing, secondary antibodies incubation, and fluorescence detection are completed according to the manufacturer's instruction

\section{RNAseq Profiling and Bioinformatics Analysis}

RNAseq analysis was performed to investigate IFNy-induced genes in A549 cell lines by using HiSeq 4000 with paired-end 150 bp sequencing. Genes with > 1-fold change (log2) in expression levels in IFNy-treated A549 compared to parental A549 cells were consequently analyzed using NetworkAnalyst (http://www.networkanalyst.ca/). Pathway activations were selected and matched according to the PANTHER database.

\section{Isolation of peripheral blood mononuclear cells (PBMCs) and $\mathrm{CD}^{+} \mathrm{T}$ cells}

The procedure for PBMCs and $\mathrm{CD}^{+} \mathrm{T}$ cell isolation was the same described previously [9]. In brief, blood was collected and analyzed from the individual healthy volunteer ( $n=16$, Table S1) in Mackay Memorial Hospital, Taipei, Taiwan. $6 \mathrm{~mL}$ of buffy coats were isolated from $20 \mathrm{~mL}$ of whole blood by an initial $1200 \mathrm{rpm}$ centrifugation for $30 \mathrm{~min}$. The collected $1 \mathrm{~mL}$ of buffy coats was mixed with $7 \mathrm{~mL}$ of PBS buffer and loaded onto the $4 \mathrm{~mL}$ of ficoll solution and consequently for $2000 \mathrm{rpm}$ gradient centrifugation for $20 \mathrm{~min}$. PBMCs on the interface between the plasma and ficoll media were collected for further analysis. The CD8 ${ }^{+} \mathrm{T}$ cell isolation kit (Miltenyi Biotec, North Rhine-Westphalia, Germany) was used to isolate CD ${ }^{+} \mathrm{T}$ cells from the PBMCs. The isolation steps were followed based on the manufacturer's manual.

\section{Chromatin immunoprecipitation (ChIP)}

In brief, $1 \times 10^{7}$ A549 cells were treated with $20 \mathrm{ng} / \mathrm{ml}$ of IFNy for $1.5 \mathrm{~h}$ or sequentially treated by $20 \mathrm{ng} / \mathrm{ml}$ of IFNy for $2 \mathrm{~h}$ with $20 \mathrm{ng} / \mathrm{ml}$ of EGF for $1.5 \mathrm{~h}$. After treatment, A549 cells were fixed by $1 \%$ formaldehyde and fragmentized by sonication. A549 cells were resuspended and incubated with control IgG, anti-STAT3, and anti-STAT1 antibody (Cell Signaling, Danvers, Massachusetts, USA) at $4^{\circ} \mathrm{C}$ overnight for immunoprecipitation. After incubation, the antibodies were captured by Dynabead-Protein A (Life Technologies, Waltham, Massachusetts, USA). The Dynabeads were washed and consequently pulled down by a Sample Magnetic Rack. DNA fragments were eluted by boiling the Dynabeads and concentrated by a FavorPrep GEL/PCR Purification Mini Kit (Favorgen Biotech Corp., Wembley, WA, Australia). The DNA preparation was analyzed by real-time PCR using Fast SYBR Green Master Mix (Applied Biosystem, CA, USA) with primer pairs shown in 
Table 1. The primer sequences amplify the PDL1 and MCL1 promoter predicted from PROMO (http://alggen.Isi.upc.es/).

\section{Statistical analysis}

Statistical analyses were performed using GraphPad Prism V8.01 (GraphPad Software, Inc., California, USA). All analytical data with more than two groups were evaluated using analysis of variance, followed by post hoc analysis with Bonferroni's test. The student's t-test was used to compare two groups. Moreover, $p<0.05$ was considered to indicate a statistically significant difference.

\section{Results}

\section{Irradiation and PBMCs synergistically inhibited tumor cell viability and induced apoptosis in lung cancer cells}

To investigate whether irradiation augments immunological surveillance against NSCLC cells, the EGFRpositive tumor cell lines, including A549 (wild-type EGFR; KRAS mutation), HCC827, PC9, and H1650 (EGFR E746-A750 deletion: autophosphorylation), were selected for treatments with irradiation and the isolated healthy PBMCs. Cell viability and apoptosis were then measured. We found that irradiation significantly suppressed cell viability on A549, HCC827, PC9, and H1650 (Fig. 1A). In addition, 20 Gy of irradiation increased late apoptosis rates on A549, HCC827, and PC9 (Fig. 1B), and early apoptosis rates on HCC827 and PC9 (Fig. 1B). By contrast, CD8 ${ }^{+}$T cells significantly suppressed HCC827, PC9, and H1650 cell viabilities but did not on A549 (Fig. 1C). We noticed that HCC827 pre-incubated CD8 ${ }^{+} \mathrm{T}$ cells possessed higher cytotoxic efficacy than the parental CD8 ${ }^{+} \mathrm{T}$ cells to suppressing cell viability on HCC827, but the phenomena did not observe on A549 cells (Fig. 1C). Furthermore, A549 cell line was selected as CD ${ }^{+}$T-resistant model to investigate the synergistic effect of irradiation on immunological surveillance. We found that combined irradiation and PBMCs treatment significantly led to remarkable inhibition on A549 (Fig. 1D), also increased late apoptosis and dead cell rates compared to individual irradiation or PBMCs treatment (Fig. 1E).

\section{Reactivation of healthy CD8 ${ }^{+} \mathrm{T}$ cells in encountering HCC827 and A549 in vitro}

To further investigate the mechanism on A549 cells resisting cytotoxicity of the healthy $\mathrm{CD}^{+}{ }^{+} \mathrm{T}$ cells, the antitumor status of reactivation on immune surveillance was measured, particularly T lymphocytes. We first measured the percentages of Naïve, central memory (CM), effector memory (EM), and terminally differentiated effector memory (TDEM) in the isolated healthy PBMCs through detecting CD45RA and CCR7 using flow cytometry (Fig. 2A). The percentage of the reactivation markers, including CD16, CD25 (IL2RA), CD28, CD122 (IL2RB), CD178 (FASL), and inhibitory marker CD279 (PD-1) were measured in the isolated healthy PBMCs depending on $\mathrm{CD}^{+}$or $\mathrm{CD} 8^{+}$lymphocytes (Fig. 2B). We noticed and validated that CD16 and CD122 were positively correlated in $\mathrm{CD}^{+}$and $\mathrm{CD}^{+} \mathrm{T}$ cells (Fig. $2 \mathrm{C}$ ). The personal characteristics of the enrolled volunteers were shown in Table S1 and Table S2. Moreover, we found that CD16-high expression $\mathrm{CD}^{+} \mathrm{T}$ cells were able to significantly inhibited HCC827 cell viability compared to CD16-low expression CD ${ }^{+}$ T cells (Fig. 2D). To make sure $\mathrm{CD}^{+} \mathrm{T}$ cells were reactivated by tumor cells, the PBMCs were co-incubated 
with HCC827 and A549 cells for $24 \mathrm{~h}$ and $\mathrm{CD} 8^{+} \mathrm{T}$ cells were isolated and analyzed consequently. The GZMB as the reactivation marker for $\mathrm{CD} 8^{+} \mathrm{T}$ cells and the qPCR results revealed that $\mathrm{HCC} 827$ and $\mathrm{A} 549$ both activated $\mathrm{CD}^{+} \mathrm{T}$ cells (Fig. 2E). Meanwhile, A549 pre-treated with IFNy for $2 \mathrm{~h}$ caused a remarkable increase of GZMB in isolated CD8 ${ }^{+}$T cells (Fig. 2E). Moreover, CD16 and CD122 both increased in HCC827-incubated $\mathrm{CD} 8^{+} \mathrm{T}$ cells and only CD122 increased in A549-incubated CD8 ${ }^{+} \mathrm{T}$ cells (Fig. 2F). Since we demonstrated that irradiation improved anti-tumor cytotoxicity of PBMCs (Fig. 1D and 1E), the irradiation marker ISG15 was measured and it increased in irradiated A549 in a dose-dependent manner (Fig. 2G). ISG15 is a secreted protein playing as a cytokine to activate CD $8+T$ cells through LFA-1 receptor [47]. Therefore, the cultured medium was collected and added to PBMCs, and GZMB and IFNy expressions were measured in $\mathrm{CD} 8^{+} \mathrm{T}$ cells. We found that $A 549$ cells stimulated $C D 8^{+} T$ cells to express GZMB (Fig. $2 \mathrm{H}$ ) but supernatant medium stimulated CD8 ${ }^{+}$T cells to express IFNy (Fig. 2I). In addition, A549 and irradiated A549 both stimulated PBMCs to secret IFNy in $24 \mathrm{~h}$ of incubation, rather than HCC827 (Fig. 2J).

\section{IFNy dominantly phosphorylated STAT3 in the premise of phosphorylated EGFR}

IFNy is a cytokine secreted by $\mathrm{T}$ lymphocytes for further stimulating macrophages and $\mathrm{CD} 8^{+} \mathrm{T}$ cells. The increase of GZMB and IFNY in $\mathrm{CD} 8^{+} \mathrm{T}$ cells and in the medium of the cell mixture, respectively, indicated that the $\mathrm{CD} 8^{+} \mathrm{T}$ cells were reactivated after $\mathrm{A} 549$ co-culture but we found $\mathrm{A} 549$ remained resistant to $\mathrm{CD} 8^{+} \mathrm{T}$ cells. The IFNY-mediated downstream signaling pathways were investigated furthermore, such as STAT1 and STAT3 phosphorylation and PD-L1 expression in A549 cells. A549 (EGFR wild-type) and HCC827, PC9, H1650 (EGFR E746-A750 deletion with auto-phosphorylation) highly expressed EGFR and PD-L1 (Fig. 3A). In addition, the four cell lines were CD44-positive, and A549 and HCC827 expressed CD133 higher than PC9 and H1650 (Fig. 3A). We noticed that A549 and PC9 expressed EGFR and PD-L1 higher than HCC827 and H1650 (Fig. 3B). A549, HCC827, and PC9 were selected and compared for phosphorylations on STAT1 and STAT3. We found intrinsic STAT3 phosphorylation in HCC827 and PC9 cells but no STAT1 phosphorylation was detected in the selected cell lines (Fig. 3C). Further investigation revealed that IFNy increased phosphorylation on STAT1 and STAT3 in HCC827 and A549 (Fig. 3D). Interestingly, consequent and synergic EGF treatment highly elicited IFNY-mediated STAT3 phosphorylation with simultaneous inhibition of STAT1 phosphorylation (Fig. 3D). No effect of EGF was found on HCC827 because that HCC827 was an EGFR autophosphorylated cell line. The immune checkpoints, including PD-L1, galactin-9, and HVEM were measured using qPCR in the arranged treatments. We demonstrated that IFNy significantly increased PD-L1 and consequent and synergic EGF treatment increased IFNY-mediated PD-L1 expression in A549 cells (Fig. 3E).

\section{IFNy increased MCL1 expression in the premise of phosphorylated EGFR}

Besides PD-L1 overexpression in A549 to exhaust CD8 ${ }^{+} \mathrm{T}$ cells, we further investigated the mechanism eliciting resistance against $\mathrm{CD} 8^{+} \mathrm{T}$ cells in A549 cells. RNAseq was used to investigate the differential gene expression derived by IFNy treatment. The differential genes $>2$ and $<-2$ fold changes with $p$-value $<0.001$ 
were selected and analyzed (Fig. 4A and Table S3). NetworkAnalst revealed the driver gene from the IFNYincreased differential genes, including PSMB8, PSMB10, NFKB2, SOCS3, UBE2L6, STAT1, EFNA1, PML, FASL1, MCL1, and STAT2 (Fig. 4B). After validation using qPCR, SOCS3, UBE2L6, STAT1, FASL1, MCL1 were significantly increased in IFNy-treated A549 (Fig. 4C). The five genes were associated with survival probability in patients with lung cancer using Kaplan-Meier plotter analysis, which demonstrated that increase of each gene was associated with poor survival rate (Fig. 4E). SOCS3 and MCL1 were particularly investigated since literature indicated that they were associated with apoptosis [38] and anti-apoptosis function [58], respectively. PBMCs co-culture significantly increased SOCS3 and MCL1 expression in A549 cells (Fig. 4D). Particularly PBMCs elicited higher SOCS3 and MCL1 expression in IFNy-pretreated A549 cells (Fig. 4D). We also found that individual EGF and IFNy increased SOCS3 expression in A549 (Fig. 4E) and consequent and synergic EGF with IFNy increased MCL1 expression in A549 (Fig. 4E). The MCL1 expression was positively correlated with PD-L1 expression in the arranged treatments (Fig. 4F).

\section{Irradiation specifically blocked IFNy-mediated phosphorylations on STAT1 and STAT3 in A549 cells}

The IFNY-mediated phosphorylations on STAT1 and STAT3, and gene expressions on PD-L1, SOCS3, and MCL1 were detected in irradiation-treated A549 cells. The results indicated that $20 \mathrm{~Gy}$ of irradiation specifically inhibited IFNY-mediated STAT1 phosphorylation and synergic effect of EGF with IFNY on STAT3 phosphorylation (Fig. 5A). PD-L1, SOCS3, and MCL1 expressions were consequently reduced in 20 Gy of irradiation treatment compared to the corresponding arranged treatments (Fig. 5B).

\section{STAT3 dominantly determined IFNy-mediated gene expression and knockdown of STAT3-mediated MCL1 augmented PBMCs against A549 cells}

To ensure that irradiation-inhibited phosphorylations on STAT1 and STAT3 augmented PBMCs-mediated antitumor effect, STAT1 and STAT3 were knockdowned and PD-L1, SOCS3, and MCL1 expressions were measured and investigated. We found that STAT3 knockdown significantly reduced IFNY-mediated PD-L1 expression (Fig. 6A). However, STAT1 knockdown did not affect IFNy-mediated PD-L1 expression (Fig. 6B). We also demonstrated that IFNY-mediated SOCS3 and MCL expressions were decreased in A549shSTAT3 cells but not in A549shSTAT1 cells when compared to A549shLuc cells (Fig. 6C). To clarify the potential regulatory mechanism, we used ChIP to investigate whether STAT3 and STAT1 directly bind to the promoters of individual PD-L1 and MCL1. The results revealed that STAT3 and STAT1 both were able to bind to the promoters of PD-L1 (Fig. 6D) and MCL1 (Fig. 6E) in IFNY and IFNY with consequent EGF treatments.

Furthermore, PD-L1 and MCL1 were knockdowned in A549 cells, the four stable A549 knockdown cell lines, including A549shPD-L1, A549shSTAT3, A549shSTAT1, and A549shMCL1 were further investigated compared to A549shLuc after co-cultured with individual healthy PBMCs. We found that cell viability was decreased in A549shSTAT3 and A549shMCL1 compared to A549shLuc in PBMCs treatment for $48 \mathrm{~h}$ (Fig. 6F). Knockdown of PD-L1 and STAT1 did not affect the PBMCs cytotoxicity against A549 and knockdown of STAT1 slightly increased cell viability (Fig. 6F). To address and validate that MCL1 elicited resistance to the cytotoxicity of PBMCs, apoptosis was measured in A549shMCL1 with irradiation and PBMCs treatments. The results 
demonstrated that knockdown of MCL1 increased A549 cell death rate in 20 Gy with PBMCs treatment compared to control A549shLuc cells (Fig. 6G).

\section{Discussion}

In this study, we used healthy PBMCs to investigate the mechanism of IR augmentation for clinical tumor immunotherapies but the status of immune surveillance is ultimately different between healthy volunteers and tumor patients, including macrophages and T lymphocytes. Literature has indicated that macrophages are usually classified as M1 (classical-activated macrophages) and M2 (tumor-associated macrophages, TAMs) phenotype [8], that M1 macrophages enhance inflammation response against initial tumor cells, but M2 macrophages suppresses immune system to trigger tumor progression. TAMs enriched in the tumor microenvironment. Moreover, $\mathrm{CD}^{+} \mathrm{T}$ cells are exhausted in patients with tumors. Exhausted CD8 ${ }^{+} \mathrm{T}_{\text {cells }}$ are characterized by loss of cytotoxic functions with increased expression of multiple inhibitory receptors such as PD-1 and decreased secretion of effector cytokines such as IFNy. Current immunotherapies are mainly designed to reactivate the immune system in tumor patients. For example, TAMs as a therapeutic target [20] that the TAM-targeted therapeutics are mainly focused on to eliminate M2 or educate M2 to transfer to M1 phenotype [45]. Reactivation of the exhausted $C D 8^{+} \mathrm{T}$ cells with inhibitory receptor blockade promotes immunity and survival outcome in tumor patients. Besides, $C D 8^{+} \mathrm{T}$ cells can also be activated by inserting a specific TCR recognizing tumor antigen called chimeric antigen receptor T-cell therapy (CAR-T). Once activation in $\mathrm{CD}^{+} \mathrm{T}$ cells, IFNy is secreted and the function of which is to bind and activates macrophages to induction of M1 differentiation [36, 44]. However, IFNy also induced JAKs-STATs signaling pathways in tumor cells. We clarified the potential IFNy-mediated mechanism resisting to cytotoxicity of $\mathrm{CD}^{+}{ }^{+} \mathrm{T}_{\text {cells }}$ through expressing MCL1 in EGFR-positive NSCLC in this study.

We have previously demonstrated that CD16 (FcyRIIIA) and CD122 (IL2/IL15R ) are correlated in the healthy $\mathrm{CD}^{+} \mathrm{T}$ cells [11]. This study also evaluated and demonstrated CD16-highly expressed CD ${ }^{+} \mathrm{T}$ cells possessed higher anti-HCC827 capacity compared to CD16-low expressed CD ${ }^{+} \mathrm{T}$ cells. To our knowledge, CD16 on $\mathrm{CD}^{+} \mathrm{T}$ cells acts as an activation site exerting antibody-dependent cellular cytotoxicity (ADCC) function, the levels of which are decreased in exhausted $C D 8^{+} T$ cells treated by nicotine treatment and in smokers [11]. CD16 ${ }^{+} \mathrm{CD}^{+} \mathrm{T}$ cells exhibit natural killer (NK)-like and are terminally differential memory effector T phenotype with high levels of granzyme B and perforin [6, 40], indicating this small group of effector $\mathrm{CD}^{+} \mathrm{T}$ cells may exhibit anti-tumor potential since granzyme $\mathrm{B}$ and perforin causes tumor apoptosis. The unconventional NK-like [KIR/NKG2A(+)Eomes(+)] CD8 ${ }^{+} \mathrm{T}$ cells with TDEM phenotype [CD45RA(+)CCR7(-)] have innate features and able to secrete IFNy rapidly following stimulations compared to conventional memory [KIR/NKG2A(-)Eomes(+)] CD8 ${ }^{+}$T cells [59]. Moreover, CD16 is frequently increased in the unconventional NK-like $\mathrm{CD}^{+} \mathrm{T}$ cells [4]. To our knowledge, Eomes determines the differentiation of CD8 ${ }^{+}$ T cells into effector and memory phases and regulates CD122 expression [30]. CD122 is the receptor of IL2 and IL 15 contributing to $T$ cell proliferation and granzyme B expression through activating JAKs-STAT5. A literature has indicated that IL 15 is able to substantially increase CD16 expression in CD ${ }^{+} T$ cells [4]. In addition, IL2 is used in clinical applications to against tumors. Based on the evidence, $\mathrm{CD} 16^{+} \mathrm{CD}_{122^{+} \mathrm{CD} 8^{+} \mathrm{T}}$ 
cells may reflect the reactivation of $\mathrm{CD} 8^{+} \mathrm{T}$ cells as a biomarker of cancer immunotherapies since they are surface receptors to be easily detected.

EGFR overexpressed in the selected cell lines, including A549, HCC827, PC9, and H1650, and intrinsic PD-L1 expression was detected. The EGFR autophosphorylation has been reported in HCC827, PC9, and H1650, which may lead to highly phosphorylation of STAT3 (Fig. 3C). Since the characteristic, EGF had no effect on STAT3 phosphorylation but IFNy caused highly STAT3 phosphorylation in HCC827. Same phenomena were observed in the sequential treatment of EGF and IFNy in A549 (Fig. 3D). It also validated and revealed that STAT3 phosphorylation suppressed STAT1 phosphorylation, indicating the possibility the lower levels of PDL1 in HCC827 compared to that in A549. We expected that low levels of STAT1 and pSTAT1 in HCC827 resulted in susceptibility to the cytotoxicity of $\mathrm{CD} 8^{+} \mathrm{T}$ cells since we demonstrated that STAT1 bound to the promoter of PD-L1 and MCL1. Compared to HCC827, there was an instant increase of MCL1 in the sequential IFNy with EGF-treated A549 (Fig. 4F). Meanwhile, JAKs-STATs signaling axis also regulated $\mathrm{MHCl}$ expression $[32,60]$. We found that IFNy specifically increased non-classical MHCI HLA-E molecules which is the ligand of CD94/NKG2 receptors expressed in NK cells and a subset of CD8 ${ }^{+} \mathrm{T}$ cells [48]. Therefore, IFNy-pretreated A549 exhibited higher immunogenic capacity to immunity since we uncovered the isolated $\mathrm{CD} 8^{+} \mathrm{T}$ cells with highly granzyme B expression (Fig. 2E). However, IFNY-pretreated A549 also expressed highly MCL1 expression responding to PBMCs (Fig. 4D). This study provides evidence suggesting that IFNY-mediated JAKs-STATs axis plays a double-edged sword in NSCLC stimulating reactivation of CD8 ${ }^{+} \mathrm{T}$ cells but increasing anti-apoptosis MCL1 expression in A549.

This study provides evidence that IR enhances the reactivation of $C D 8^{+} T$ cells against NSCLC through specifically inhibiting phosphorylation of STAT1 and STAT3 and reducing the IFNY-mediated anti-apoptosis MCL1 expression. IR is considered to break DNA and leads to consequent tumor apoptosis as reliable tumor therapy. Although previous studies have indicated that tumor cells under IR-mediated stress trends to stimulate STAT3 activation for spontaneous defends to DNA damage and cellular apoptosis [23]. With sufficient IR strength causing irreversible progress such as $20 \mathrm{~Gy}$ in this study, cellular cytosolic DNA activates cGAS-STING signaling pathway and results in type 1 IFN-mediated ISG15 expression. ISG15, therefore, secreted by IR-treated tumors play as a cytokine that activates $C D 8^{+} T$ cells through binding to LFA1 receptor, resulting in IFNy expression in $\mathrm{CD}^{+} \mathrm{T}$ cells [47]. Interestingly, this study demonstrated that IR suppressed phosphorylation on STAT1 and STAT3 specifically. We speculated that SHP1/2 may be activated by IR $[29,33]$, which dephosphorylated STAT1 and STAT3. Based on the findings, we demonstrated a new mechanism of radiotherapy to augment immunity, that may indicate that radiotherapy enhances anti-tumor efficacy of immunotherapies in clinical practice.

\section{Conclusions}

In this study, we demonstrated that IR elicited A549 cell apoptosis and augmented PBMCs-mediated cell death through prohibiting IFNY and EGF-mediated phosphorylations on STAT1 and STAT3 and gene overexpression on PD-L1 and MCL1 (Fig. 7). Healthy CD8 ${ }^{+}$T cells were stimulated and reactivated in cocultured with HCC827 and A549 since granzyme B (GZMB) and IFNy were increased. Granzyme B was considered a hydrolase enzyme leading to tumor cell apoptosis but $C D 8^{+} \mathrm{T}$ also secreted IFNY and resulted in 
STAT3-mediated MCL1 expression against cell apoptosis. We figured out the mechanism of IR augmented immune surveillance against EGFR-positive NSCLC in this study.

\section{Declarations}

\section{ACKNOWLEDGMENTS}

The authors thank the Radiation Biology Core Laboratory of the Institute for Radiological Research, Chang Gung Memorial Hospital, for technical support.

\section{AUTHORS' CONTRIBUTIONS}

Y-F Chang, C-CCheng and A-SHo conceptualized and designed the study. C-I Wang, C-CCheng and Z-LSie developed the methodology. C-I Wang, C-CCheng and Z-LSie collected the data. C-CCheng and C-CChang analyzed and interpreted the data (e.g., statistical analysis, biostatistics, and computational analysis). C-I Wang, Y-F Chang, and C-CCheng contributed toward writing, reviewing, and revising the manuscript. A-SHo and C-CChang supervised the study. All authors read and approved the final manuscript.

\section{FUNDING}

This study was supported by grants from the Ministry of Science and Technology of Taiwan (MOST 1092314-B-182-011 and 110-2314-B-182-003-MY3).

\section{AVAILABILITY OF DATA AND MATERIALS}

Not applicable.

\section{ETHICS APPROVAL AND CONSENT TO PARTICIPATE}

The clinical blood was acquired in Mackay Memorial Hospital, Taipei, Taiwan according to the protocol approved by regulatory authorities and Institutional Review Boards in Mackay Memorial Hospital (20MMHIS018e).

\section{CONSENT FOR PUBLICATION}

Not applicable.

\section{CONFLICT OF INTEREST}

We declare no conflict of interest for this article.

\section{ANIMAL SOURCE}

Not applicable.

\section{CELL LINE AUTHENTICATION}


The lung cancer cell lines A549, HCC827 and PC9 and H1650were purchased from the American Type Culture Collection (ATCC, Manassas, VA, USA); HCC827 and A549 were reauthenticated through short tandem repeat profiling (Applied Biosystems, Massachusetts, USA): HCC827 on May 8, 2015; A549 on June 4, 2014.

\section{References}

1. Anagnostou V.K. and Brahmer J.R. Cancer immunotherapy: a future paradigm shift in the treatment of non-small cell lung cancer. Clin Cancer Res 21(5):976-984, 2015.

2. Apetoh L., Ghiringhelli F., Tesniere A., Obeid M., Ortiz C., Criollo A., Mignot G., Maiuri M.C., Ullrich E., Saulnier P., Yang H., Amigorena S., Ryffel B., Barrat F.J., Saftig P., Levi F., Lidereau R., Nogues C., Mira J.P., Chompret A., Joulin V., Clavel-Chapelon F., Bourhis J., Andre F., Delaloge S., Tursz T., Kroemer G. and Zitvogel L. Toll-like receptor 4-dependent contribution of the immune system to anticancer chemotherapy and radiotherapy. Nat Med 13(9):1050-1059, 2007.

3. Aragane Y., Kulms D., Luger T.A. and Schwarz T. Down-regulation of interferon gamma-activated STAT1 by UV light. Proc Natl Acad Sci U S A 94(21):11490-11495, 1997.

4. Barbarin A., Cayssials E., Jacomet F., Nunez N.G., Basbous S., Lefevre L., Abdallah M., Piccirilli N., Morin B., Lavoue V., Catros V., Piaggio E., Herbelin A. and Gombert J.M. Phenotype of NK-Like CD8(+) T Cells with Innate Features in Humans and Their Relevance in Cancer Diseases. Front Immunol 8:316, 2017.

5. Bironzo P. and Di Maio M. A review of guidelines for lung cancer. J Thorac Dis 10(Suppl 13):S1556S1563, 2018.

6. Bjorkstrom N.K., Gonzalez V.D., Malmberg K.J., Falconer K., Alaeus A., Nowak G., Jorns C., Ericzon B.G., Weiland O., Sandberg J.K. and Ljunggren H.G. Elevated numbers of Fc gamma RIIIA+ (CD16+) effector CD8 T cells with NK cell-like function in chronic hepatitis C virus infection. J Immunol 181(6):4219-4228, 2008.

7. Bray F., Ferlay J., Soerjomataram I., Siegel R.L., Torre L.A. and Jemal A. Global cancer statistics 2018: GLOBOCAN estimates of incidence and mortality worldwide for 36 cancers in 185 countries. CA Cancer J Clin 68(6):394-424, 2018.

8. Chen Y., Song Y., Du W., Gong L., Chang H. and Zou Z. Tumor-associated macrophages: an accomplice in solid tumor progression. J Biomed Sci 26(1):78, 2019.

9. Cheng C.-C., Lin H.-C., Chiang Y.-W., Chang J., Sie Z.-L., Yang B.-L., Lim K.-H., Peng C.-L., Ho A.-S. and Chang Y.-F. Nicotine exhausts CD8+ T cells against tumor cells through increasing miR-629-5p to repress IL2RB-mediated granzyme B expression. Cancer Immunology, Immunotherapy, 2020.

10. Cheng C.C., Chang J., Huang S.C., Lin H.C., Ho A.S., Lim K.H., Chang C.C., Huang L., Chang Y.C., Chang Y.F. and Wu C.W. YM155 as an inhibitor of cancer stemness simultaneously inhibits autophosphorylation of epidermal growth factor receptor and G9a-mediated stemness in lung cancer cells. PLoS One 12(8):e0182149, 2017.

11. Cheng C.C., Lin H.C., Chiang Y.W., Chang J., Sie Z.L., Yang B.L., Lim K.H., Peng C.L., Ho A.S. and Chang Y.F. Nicotine exhausts CD8(+) T cells against tumor cells through increasing miR-629-5p to repress IL2RB-mediated granzyme B expression. Cancer Immunol Immunother, 2020. 
12. Cheng C.C., Lin H.C., Tsai K.J., Chiang Y.W., Lim K.H., Chen C.G., Su Y.W., Peng C.L., Ho A.S., Huang L., Chang Y.C., Lin H.C., Chang J. and Chang Y.F. Epidermal growth factor induces STAT1 expression to exacerbate the IFNr-mediated PD-L1 axis in epidermal growth factor receptor-positive cancers. Mol Carcinog 57(11):1588-1598, 2018.

13. Cheng C.C., Yang B.L., Chen W.C., Ho A.S., Sie Z.L., Lin H.C. and Chang C.C. STAT3 Mediated miR-30a-5p Inhibition Enhances Proliferation and Inhibits Apoptosis in Colorectal Cancer Cells. Int J Mol Sci 21(19), 2020.

14. Cullen S.P., Brunet M. and Martin S.J. Granzymes in cancer and immunity. Cell Death Differ 17(4):616$623,2010$.

15. Dovedi S.J., Adlard A.L., Lipowska-Bhalla G., McKenna C., Jones S., Cheadle E.J., Stratford I.J., Poon E., Morrow M., Stewart R., Jones H., Wilkinson R.W., Honeychurch J. and Illidge T.M. Acquired resistance to fractionated radiotherapy can be overcome by concurrent PD-L1 blockade. Cancer Res 74(19):54585468, 2014.

16. Ettinger D.S., Aisner D.L., Wood D.E., Akerley W., Bauman J., Chang J.Y., Chirieac L.R., D'Amico T.A., Dilling T.J., Dobelbower M., Govindan R., Gubens M.A., Hennon M., Horn L., Lackner R.P., Lanuti M., Leal T.A., Lilenbaum R., Lin J., Loo B.W., Martins R., Otterson G.A., Patel S.P., Reckamp K., Riely G.J., Schild S.E., Shapiro T.A., Stevenson J., Swanson S.J., Tauer K., Yang S.C., Gregory K. and Hughes M. NCCN Guidelines Insights: Non-Small Cell Lung Cancer, Version 5.2018. J Natl Compr Canc Netw 16(7):807821, 2018.

17. Ettinger D.S., Wood D.E., Aisner D.L., Akerley W., Bauman J., Chirieac L.R., D'Amico T.A., DeCamp M.M., Dilling T.J., Dobelbower M., Doebele R.C., Govindan R., Gubens M.A., Hennon M., Horn L., Komaki R., Lackner R.P., Lanuti M., Leal T.A., Leisch L.J., Lilenbaum R., Lin J., Loo B.W., Jr., Martins R., Otterson G.A., Reckamp K., Riely G.J., Schild S.E., Shapiro T.A., Stevenson J., Swanson S.J., Tauer K., Yang S.C., Gregory K. and Hughes M. Non-Small Cell Lung Cancer, Version 5.2017, NCCN Clinical Practice Guidelines in Oncology. J Natl Compr Canc Netw 15(4):504-535, 2017.

18. Forde P.M. and Ettinger D.S. Targeted therapy for non-small-cell lung cancer: past, present and future. Expert Rev Anticancer Ther 13(6):745-758, 2013.

19. Formenti S.C. and Demaria S. Systemic effects of local radiotherapy. Lancet Oncol 10(7):718-726, 2009.

20. Fujimura T., Kambayashi Y., Fujisawa Y., Hidaka T. and Aiba S. Tumor-Associated Macrophages: Therapeutic Targets for Skin Cancer. Front Oncol 8:3, 2018.

21. Fukuoka M., Wu Y.L., Thongprasert S., Sunpaweravong P., Leong S.S., Sriuranpong V., Chao T.Y., Nakagawa K., Chu D.T., Saijo N., Duffield E.L., Rukazenkov Y., Speake G., Jiang H., Armour A.A., To K.F., Yang J.C. and Mok T.S. Biomarker analyses and final overall survival results from a phase III, randomized, open-label, first-line study of gefitinib versus carboplatin/paclitaxel in clinically selected patients with advanced non-small-cell lung cancer in Asia (IPASS). J Clin Oncol 29(21):2866-2874, 2011.

22. Ganss R., Ryschich E., Klar E., Arnold B. and Hammerling G.J. Combination of T-cell therapy and trigger of inflammation induces remodeling of the vasculature and tumor eradication. Cancer Res 62(5):1462$1470,2002$.

23. Gao L., Li F.S., Chen X.H., Liu Q.W., Feng J.B., Liu Q.J. and Su X. Radiation induces phosphorylation of STAT3 in a dose- and time-dependent manner. Asian Pac J Cancer Prev 15(15):6161-6164, 2014. 
24. Garcia-Diaz A., Shin D.S., Moreno B.H., Saco J., Escuin-Ordinas H., Rodriguez G.A., Zaretsky J.M., Sun L., Hugo W., Wang X., Parisi G., Saus C.P., Torrejon D.Y., Graeber T.G., Comin-Anduix B., Hu-Lieskovan S., Damoiseaux R., Lo R.S. and Ribas A. Interferon Receptor Signaling Pathways Regulating PD-L1 and PDL2 Expression. Cell Rep 19(6):1189-1201, 2017.

25. Gong X., Li X., Jiang T., Xie H., Zhu Z., Zhou F. and Zhou C. Combined Radiotherapy and Anti-PD-L1 Antibody Synergistically Enhances Antitumor Effect in Non-Small Cell Lung Cancer. J Thorac Oncol 12(7):1085-1097, 2017.

26. Herter-Sprie G.S., Koyama S., Korideck H., Hai J., Deng J., Li Y.Y., Buczkowski K.A., Grant A.K., Ullas S., Rhee K., Cavanaugh J.D., Neupane N.P., Christensen C.L., Herter J.M., Makrigiorgos G.M., Hodi F.S., Freeman G.J., Dranoff G., Hammerman P.S., Kimmelman A.C. and Wong K.K. Synergy of radiotherapy and PD-1 blockade in Kras-mutant lung cancer. JCI Insight 1(9):e87415, 2016.

27. Hodge J.W., Guha C., Neefjes J. and Gulley J.L. Synergizing radiation therapy and immunotherapy for curing incurable cancers. Opportunities and challenges. Oncology (Williston Park) 22(9):1064-1070; discussion 1075, 1080-1061, 1084, 2008.

28. Huang C.Y., Lin C.S., Tai W.T., Hsieh C.Y., Shiau C.W., Cheng A.L. and Chen K.F. Sorafenib enhances radiation-induced apoptosis in hepatocellular carcinoma by inhibiting STAT3. Int J Radiat Oncol Biol Phys 86(3):456-462, 2013.

29. Huang T.T., Su J.C., Liu C.Y., Shiau C.W. and Chen K.F. Alteration of SHP-1/p-STAT3 Signaling: A Potential Target for Anticancer Therapy. Int J Mol Sci 18(6), 2017.

30. Intlekofer A.M., Takemoto N., Wherry E.J., Longworth S.A., Northrup J.T., Palanivel V.R., Mullen A.C., Gasink C.R., Kaech S.M., Miller J.D., Gapin L., Ryan K., Russ A.P., Lindsten T., Orange J.S., Goldrath A.W., Ahmed R. and Reiner S.L. Effector and memory CD8+ T cell fate coupled by T-bet and eomesodermin. Nat Immunol 6(12):1236-1244, 2005.

31. Jorgovanovic D., Song M., Wang L. and Zhang Y. Roles of IFN-gamma in tumor progression and regression: a review. Biomark Res 8:49, 2020.

32. Kida H., Ihara S. and Kumanogoh A. Involvement of STAT3 in immune evasion during lung tumorigenesis. Oncoimmunology 2(1):e22653, 2013.

33. Kim D.J., Tremblay M.L. and Digiovanni J. Protein tyrosine phosphatases, TC-PTP, SHP1, and SHP2, cooperate in rapid dephosphorylation of Stat3 in keratinocytes following UVB irradiation. PLoS One 5(4):e10290, 2010.

34. Ko E.C., Raben D. and Formenti S.C. The Integration of Radiotherapy with Immunotherapy for the Treatment of Non-Small Cell Lung Cancer. Clin Cancer Res 24(23):5792-5806, 2018.

35. Kong F.M., Zhao J., Wang J. and Faivre-Finn C. Radiation dose effect in locally advanced non-small cell lung cancer. J Thorac Dis 6(4):336-347, 2014.

36. Leopold Wager C.M. and Wormley F.L., Jr. Classical versus alternative macrophage activation: the Ying and the Yang in host defense against pulmonary fungal infections. Mucosal Immunol 7(5):1023-1035, 2014.

37. Lu C., Guan J., Lu S., Jin Q., Rousseau B., Lu T., Stephens D., Zhang H., Zhu J., Yang M., Ren Z., Liang Y., Liu Z., Han C., Liu L., Cao X., Zhang A., Qiao J., Batten K., Chen M., Castrillon D.H., Wang T., Li B., Diaz 
L.A., Jr., Li G.M. and Fu Y.X. DNA Sensing in Mismatch Repair-Deficient Tumor Cells Is Essential for Antitumor Immunity. Cancer Cell 39(1):96-108 e106, 2021.

38. Lu Y., Fukuyama S., Yoshida R., Kobayashi T., Saeki K., Shiraishi H., Yoshimura A. and Takaesu G. Loss of SOCS3 gene expression converts STAT3 function from anti-apoptotic to pro-apoptotic. J Biol Chem 281(48):36683-36690, 2006.

39. Lugade A.A., Sorensen E.W., Gerber S.A., Moran J.P., Frelinger J.G. and Lord E.M. Radiation-induced IFNgamma production within the tumor microenvironment influences antitumor immunity. $\mathrm{J}$ Immunol 180(5):3132-3139, 2008.

40. Martos S.N., Campbell M.R., Lozoya O.A., Wang X., Bennett B.D., Thompson I.J.B., Wan M., Pittman G.S. and Bell D.A. Single-cell analyses identify dysfunctional CD16(+) CD8 T cells in smokers. Cell Rep Med 1(4), 2020.

41. Matsumura S., Wang B., Kawashima N., Braunstein S., Badura M., Cameron T.O., Babb J.S., Schneider R.J., Formenti S.C., Dustin M.L. and Demaria S. Radiation-induced CXCL16 release by breast cancer cells attracts effector T cells. J Immunol 181(5):3099-3107, 2008.

42. McLaughlin M., Patin E.C., Pedersen M., Wilkins A., Dillon M.T., Melcher A.A. and Harrington K.J. Inflammatory microenvironment remodelling by tumour cells after radiotherapy. Nat Rev Cancer 20(4):203-217, 2020.

43. Mellman I., Coukos G. and Dranoff G. Cancer immunotherapy comes of age. Nature 480(7378):480-489, 2011.

44. Moreira-Teixeira L., Sousa J., McNab F.W., Torrado E., Cardoso F., Machado H., Castro F., Cardoso V., Gaifem J., Wu X., Appelberg R., Castro A.G., O'Garra A. and Saraiva M. Type I IFN Inhibits Alternative Macrophage Activation during Mycobacterium tuberculosis Infection and Leads to Enhanced Protection in the Absence of IFN-gamma Signaling. J Immunol 197(12):4714-4726, 2016.

45. Pathria P., Louis T.L. and Varner J.A. Targeting Tumor-Associated Macrophages in Cancer. Trends Immunol 40(4):310-327, 2019.

46. Peng S., Wang R., Zhang X., Ma Y., Zhong L., Li K., Nishiyama A., Arai S., Yano S. and Wang W. EGFR-TKI resistance promotes immune escape in lung cancer via increased PD-L1 expression. Mol Cancer 18(1):165, 2019.

47. Perng Y.C. and Lenschow D.J. ISG15 in antiviral immunity and beyond. Nat Rev Microbiol 16(7):423-439, 2018.

48. Pietra G., Romagnani C., Manzini C., Moretta L. and Mingari M.C. The emerging role of HLA-E-restricted CD8+ T lymphocytes in the adaptive immune response to pathogens and tumors. J Biomed Biotechnol 2010:907092, 2010.

49. Platanias L.C. Mechanisms of type-I- and type-II-interferon-mediated signalling. Nat Rev Immunol 5(5):375-386, 2005.

50. Salama A.K., Postow M.A. and Salama J.K. Irradiation and immunotherapy: From concept to the clinic. Cancer 122(11):1659-1671, 2016.

51. Sehgal K., Patell R., Rangachari D. and Costa D.B. Targeting ROS1 rearrangements in non-small cell lung cancer with crizotinib and other kinase inhibitors. Transl Cancer Res 7(Suppl 7):S779-S786, 2018. 
52. Shekarian T., Valsesia-Wittmann S., Caux C. and Marabelle A. Paradigm shift in oncology: targeting the immune system rather than cancer cells. Mutagenesis 30(2):205-211, 2015.

53. Sideras K., Biermann K., Verheij J., Takkenberg B.R., Mancham S., Hansen B.E., Schutz H.M., de Man R.A., Sprengers D., Buschow S.I., Verseput M.C., Boor P.P., Pan Q., van Gulik T.M., Terkivatan T., ljzermans J.N., Beuers U.H., Sleijfer S., Bruno M.J. and Kwekkeboom J. PD-L1, Galectin-9 and CD8(+) tumor-infiltrating lymphocytes are associated with survival in hepatocellular carcinoma. Oncoimmunology 6(2):e1273309, 2017.

54. Song M., Ping Y., Zhang K., Yang L., Li F., Zhang C., Cheng S., Yue D., Maimela N.R., Qu J., Liu S., Sun T., Li Z., Xia J., Zhang B., Wang L. and Zhang Y. Low-Dose IFNgamma Induces Tumor Cell Stemness in Tumor Microenvironment of Non-Small Cell Lung Cancer. Cancer Res 79(14):3737-3748, 2019.

55. Sui H., Ma N., Wang Y., Li H., Liu X., Su Y. and Yang J. Anti-PD-1/PD-L1 Therapy for Non-Small-Cell Lung Cancer: Toward Personalized Medicine and Combination Strategies. J Immunol Res 2018:6984948, 2018.

56. Sun S., Schiller J.H. and Gazdar A.F. Lung cancer in never smokers-a different disease. Nat Rev Cancer 7(10):778-790, 2007.

57. Taniguchi Y., Yamamoto M., Ikushima H., Ohara S., Takeshima H., Sakatani T. and Usui K. Successful Treatment of Afatinib-Refractory Non-Small Cell Lung Cancer with Uncommon Complex EGFR Mutations Using Pembrolizumab: A Case Report. Case Rep Oncol 12(2):564-567, 2019.

58. Thomas L.W., Lam C. and Edwards S.W. Mcl-1; the molecular regulation of protein function. FEBS Lett 584(14):2981-2989, 2010.

59. Warren H.S., Rana P.M., Rieger D.T., Hewitt K.A., Dahlstrom J.E. and Kent A.L. CD8 T cells expressing killer Ig-like receptors and NKG2A are present in cord blood and express a more naive phenotype than their counterparts in adult blood. J Leukoc Biol 79(6):1252-1259, 2006.

60. Zhou F. Molecular mechanisms of IFN-gamma to up-regulate MHC class I antigen processing and presentation. Int Rev Immunol 28(3-4):239-260, 2009.

61. Zou S., Tong Q., Liu B., Huang W., Tian Y. and Fu X. Targeting STAT3 in Cancer Immunotherapy. Mol Cancer 19(1):145, 2020.

\section{Supplementary Information}


Table S1

Information of the enrolled healthy volunteers

\begin{tabular}{|llll|}
\hline Sample number & Age & Gender & Tumor \\
\hline P1 & 28 & female & none \\
\hline P2 & 26 & male & none \\
\hline P3 & 45 & male & none \\
\hline P4 & 21 & male & none \\
\hline P5 & 38 & male & none \\
\hline P6 & 26 & male & none \\
\hline P7 & 30 & male & none \\
\hline P8 & 45 & male & none \\
\hline P9 & 30 & male & none \\
\hline P10 & 31 & male & none \\
\hline P11 & 40 & male & none \\
\hline P12 & 34 & female & none \\
\hline P13 & 30 & male & none \\
\hline P14 & 32 & female & none \\
\hline P15 & 48 & male & none \\
\hline P16 & 30 nale & none \\
\hline
\end{tabular}


Table S2

Distribution of T cell subpopulations in the enrolled healthy volunteers

\begin{tabular}{|c|c|c|c|c|c|c|c|c|c|c|}
\hline \multirow{2}{*}{$\begin{array}{l}\text { Sample } \\
\text { number }\end{array}$} & \multicolumn{10}{|l|}{$\mathrm{CD} 4^{+}$} \\
\hline & $\begin{array}{l}\text { Naïve } \\
\text { (\%) }\end{array}$ & $\begin{array}{l}\mathrm{CM} \\
(\%)\end{array}$ & $\begin{array}{l}\mathrm{EM} \\
(\%)\end{array}$ & $\begin{array}{l}\text { TDEM } \\
\text { (\%) }\end{array}$ & $\begin{array}{l}\text { CD16 } \\
\text { (\%) }\end{array}$ & $\begin{array}{l}\text { CD25+ } \\
\text { (\%) }\end{array}$ & $\begin{array}{l}\text { CD28+ } \\
(\%)\end{array}$ & $\begin{array}{l}\text { CD122+ } \\
(\%)\end{array}$ & $\begin{array}{l}\text { CD178+ } \\
(\%)\end{array}$ & $\begin{array}{l}\text { CD279+ } \\
(\%)\end{array}$ \\
\hline P1 & 21 & 10.8 & 60.4 & 7.75 & 24.7 & 13.9 & 14.8 & 19.2 & 21.5 & 21.7 \\
\hline P2 & 31.8 & 19.5 & 41.9 & 6.76 & 23.6 & 13.3 & 13 & 14.4 & 21.2 & 13 \\
\hline P3 & 28.6 & 26 & 42.6 & 2.81 & 23.5 & 13.4 & 13.8 & 16.1 & 21.8 & 11.9 \\
\hline P4 & 20.7 & 20.9 & 53.4 & 4.98 & 23.6 & 12.5 & 11.7 & 15.2 & 22.4 & 19.5 \\
\hline P5 & 19.5 & 19.4 & 57.6 & 3.55 & 27.7 & 11.9 & 11.2 & 22.7 & 23.5 & 15 \\
\hline P6 & 30.9 & 14.6 & 46.8 & 7.58 & 28.5 & 10 & 15.7 & 25.1 & 29.1 & 17.3 \\
\hline P7 & 35.6 & 10.2 & 46.3 & 7.83 & 28.1 & 10.6 & 10.6 & 20.2 & 26.6 & 16.4 \\
\hline P8 & 26.6 & 13.9 & 47.8 & 11.7 & 25.8 & 11.9 & 11.4 & 16.5 & 22.2 & 16.6 \\
\hline P9 & 28.7 & 14.2 & 49 & 8.14 & 22.9 & 11.4 & 10.6 & 13.4 & 21.8 & 17.1 \\
\hline P10 & 46.3 & 13 & 31.6 & 9.16 & 23.3 & 12.5 & 13.4 & 13.8 & 23.3 & 14.6 \\
\hline P11 & 39 & 9.48 & 33.6 & 17.9 & 26.6 & 9.67 & 9.59 & 15.7 & 25.7 & 14.7 \\
\hline P12 & 47.7 & 23.5 & 26.5 & 2.3 & 28.8 & 10.1 & 10 & 21.6 & 27.7 & 13.4 \\
\hline P13 & 21.7 & 14.8 & 59.6 & 3.89 & 26.6 & 10.6 & 9.96 & 21.9 & 28.6 & 19.1 \\
\hline P14 & 38.6 & 7.81 & 45.8 & 7.78 & 24.8 & 9.06 & 8.53 & 15 & 24.6 & 14.4 \\
\hline P15 & 29.9 & 12.6 & 50.2 & 7.33 & 23.9 & 11.9 & 12.4 & 14.8 & 22.4 & 16.3 \\
\hline P16 & 30 & 9.48 & 51.4 & 9.16 & 27.4 & 8.07 & 8.06 & 17.7 & 27.2 & 18 \\
\hline \multirow{2}{*}{$\begin{array}{l}\text { Sample } \\
\text { number }\end{array}$} & \multicolumn{10}{|l|}{$\mathrm{CD} 8^{+}$} \\
\hline & $\begin{array}{l}\text { Naïve } \\
(\%)\end{array}$ & $\begin{array}{l}\mathrm{CM} \\
(\%)\end{array}$ & $\begin{array}{l}\mathrm{EM} \\
(\%)\end{array}$ & $\begin{array}{l}\text { TDEM } \\
(\%)\end{array}$ & $\begin{array}{l}\text { CD16 } \\
(\%)\end{array}$ & $\begin{array}{l}\text { CD25+ } \\
(\%)\end{array}$ & $\begin{array}{l}\text { CD28+ } \\
(\%)\end{array}$ & $\begin{array}{l}\text { CD122+ } \\
(\%)\end{array}$ & $\begin{array}{l}\mathrm{CD} 178^{+} \\
(\%)\end{array}$ & $\begin{array}{l}\mathrm{CD} 279^{+} \\
(\%)\end{array}$ \\
\hline P1 & 22.7 & 2.3 & 32.1 & 42.9 & 29.9 & 13.8 & 14.7 & 30.8 & 20.6 & 22.8 \\
\hline P2 & 29.2 & 4.72 & 26.7 & 39.3 & 30.7 & 12.8 & 12.6 & 23.2 & 20.3 & 17.3 \\
\hline P3 & 55 & 6.59 & 26.3 & 12.2 & 26.7 & 12.1 & 12.6 & 19.1 & 22.4 & 16.7 \\
\hline P4 & 19 & 2.54 & 33.6 & 44.8 & 40.5 & 12.7 & 11.1 & 22.7 & 19.6 & 19.5 \\
\hline P5 & 28.1 & 5.35 & 32.5 & 34 & 36.2 & 13.7 & 11.2 & 37.5 & 24.5 & 17.6 \\
\hline P6 & 23.7 & 3.07 & 32.8 & 40.4 & 44.1 & 9.79 & 15.2 & 42.3 & 29.5 & 28.6 \\
\hline P7 & 32.9 & 2.21 & 24.2 & 40.8 & 45.4 & 9.83 & 10.7 & 42.7 & 27 & 15.3 \\
\hline
\end{tabular}




\begin{tabular}{|llllllllllll|}
\hline $\begin{array}{l}\text { Sample } \\
\text { number }\end{array}$ & \begin{tabular}{l} 
CD4 $^{+}$ \\
\cline { 2 - 11 }
\end{tabular} & $\begin{array}{l}\text { Naîve } \\
(\%)\end{array}$ & $\begin{array}{l}\text { CM } \\
(\%)\end{array}$ & $\begin{array}{l}\text { EM } \\
(\%)\end{array}$ & $\begin{array}{l}\text { TDEM } \\
(\%)\end{array}$ & $\begin{array}{l}\text { CD16 } \\
(\%)\end{array}$ & $\begin{array}{l}\text { CD25 } \\
(\%)\end{array}$ & $\begin{array}{l}\text { CD28 } \\
(\%)\end{array}$ & $\begin{array}{l}\text { CD122 } \\
(\%)\end{array}$ & $\begin{array}{l}\text { CD178 } \\
(\%)\end{array}$ & $\begin{array}{l}\text { CD279 } \\
(\%)\end{array}$ \\
\hline P8 & 15.3 & 1.61 & 33.6 & 49.5 & 49.7 & 11.6 & 11 & 25.2 & 21.8 & 17.5 \\
\hline P9 & 31.1 & 4.66 & 39.3 & 24.9 & 31 & 11.3 & 10.2 & 23.5 & 23.8 & 24.2 \\
\hline P10 & 43.3 & 3.53 & 17.5 & 35.7 & 26.5 & 11.9 & 13.1 & 19.4 & 21 & 15.4 \\
\hline P11 & 31.4 & 1.86 & 17.4 & 49.3 & 34.8 & 8.83 & 8.94 & 27.1 & 26.2 & 16.7 \\
\hline P12 & 58.2 & 3.49 & 19.4 & 18.9 & 33.9 & 11 & 11.2 & 35.1 & 29.2 & 17.4 \\
\hline P13 & 21 & 1.74 & 33.9 & 43.3 & 38.3 & 10.7 & 9.48 & 36.5 & 28.2 & 29.1 \\
\hline P14 & 50 & 1.12 & 16.8 & 32.1 & 38 & 8.59 & 8.83 & 30 & 28 & 11.2 \\
\hline P15 & 9.83 & 1.49 & 43.7 & 45 & 32.1 & 11.5 & 11.5 & 29 & 22 & 20.8 \\
\hline P16 & 42.9 & 1.35 & 25.2 & 30.6 & 34.8 & 8.41 & 7.9 & 30 & 29.9 & 12.4 \\
\hline
\end{tabular}

Figures
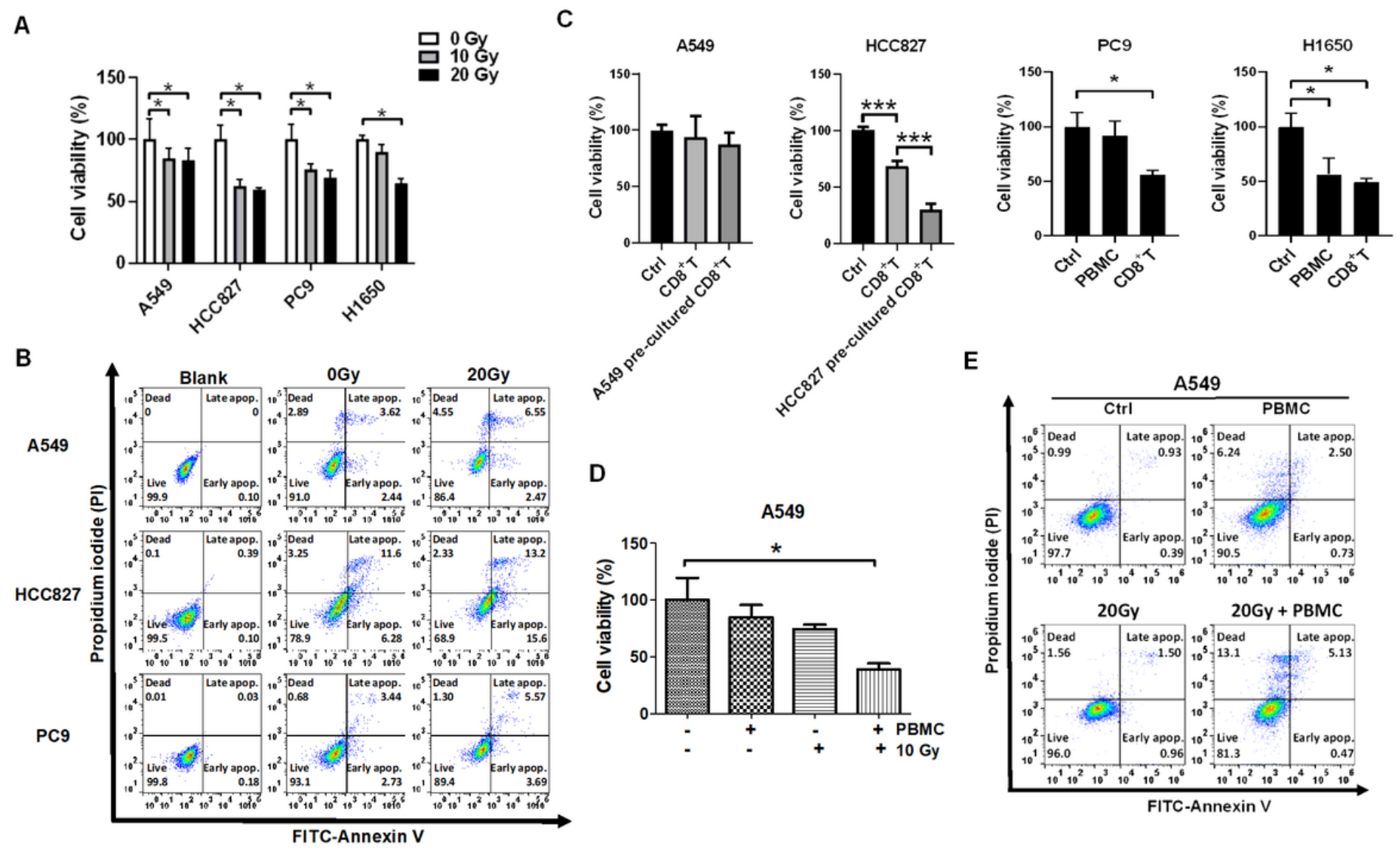

Figure 1 
A
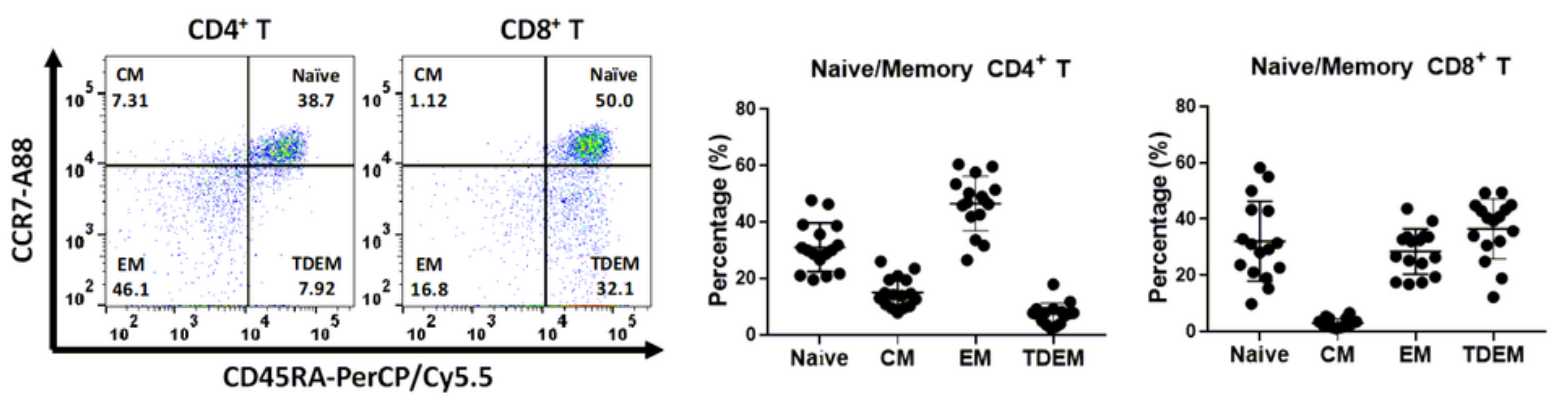

B
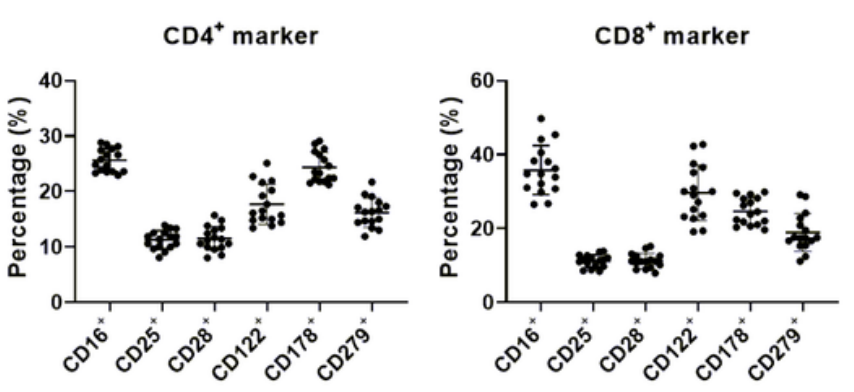

C

D

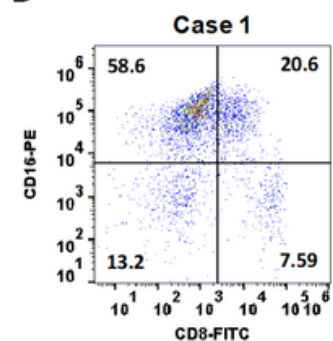

F
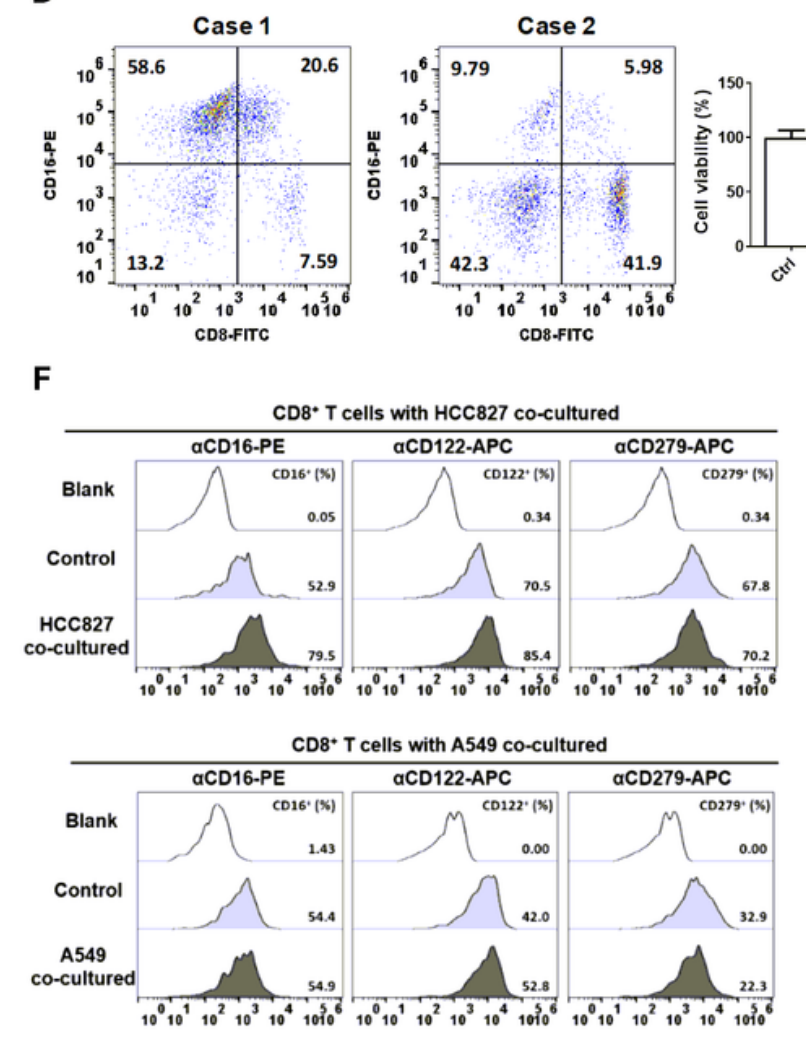

CD8-FITC

\section{Figure 2}

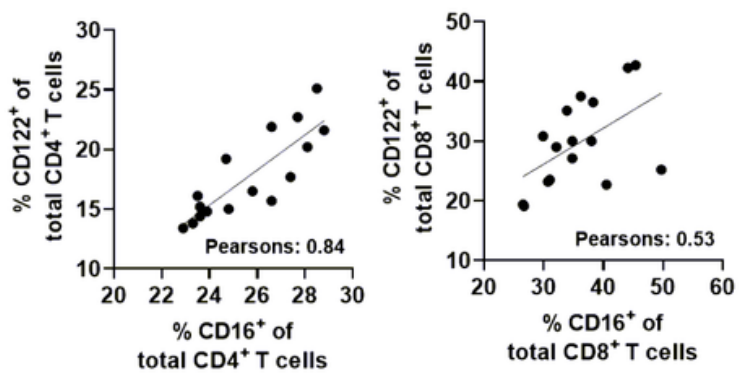

E

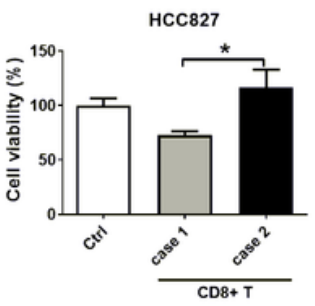

G

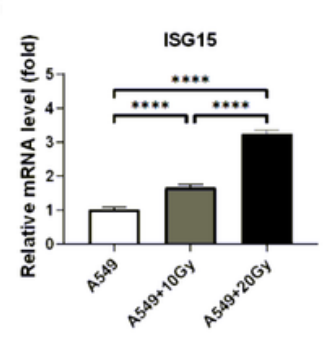

I

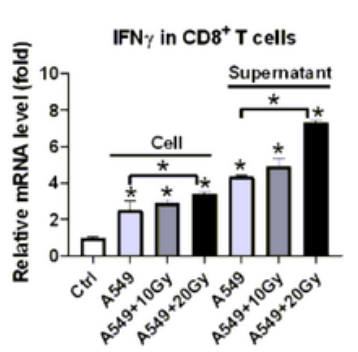

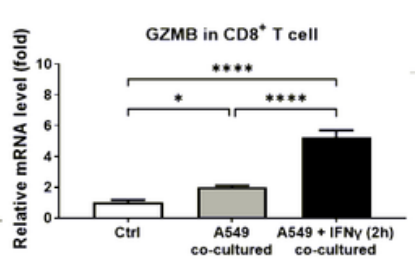

H
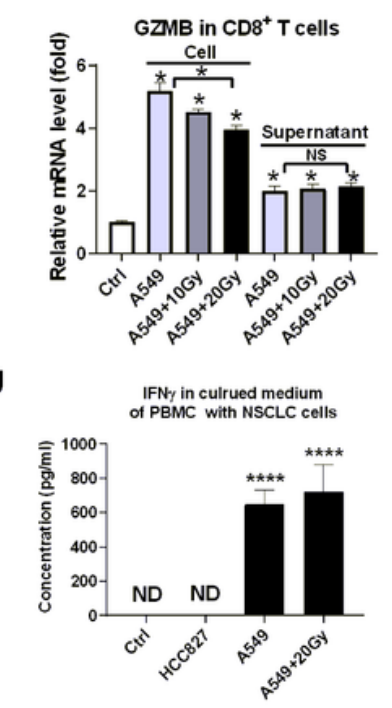


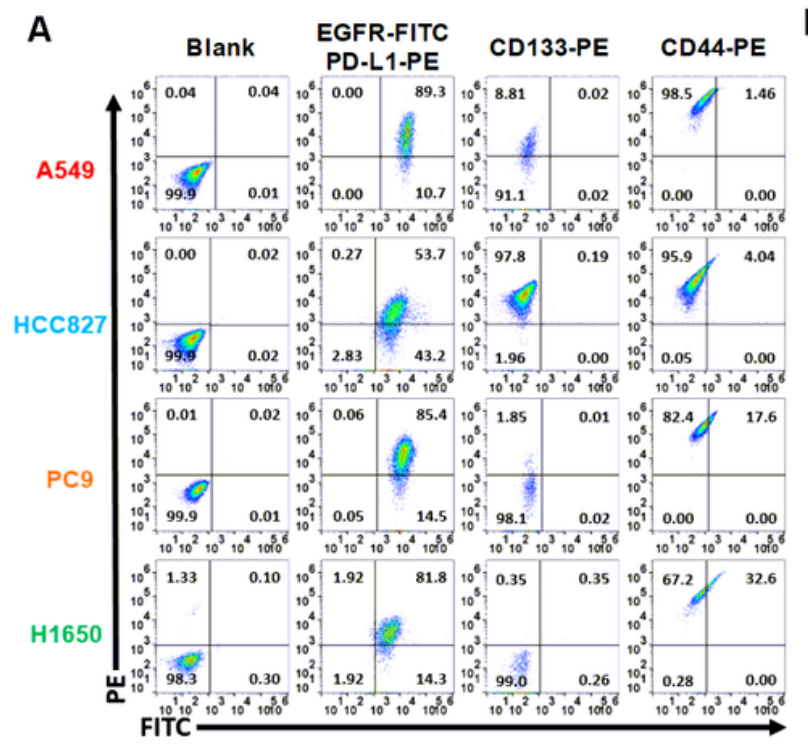

E

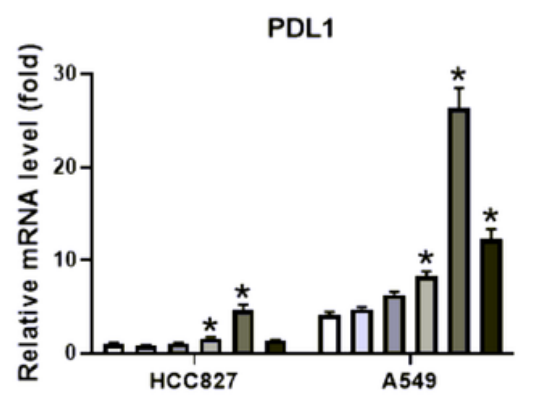

B

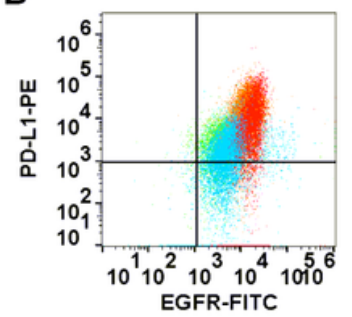

C

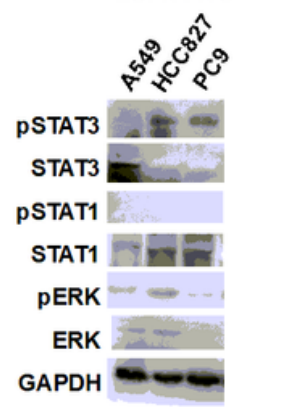

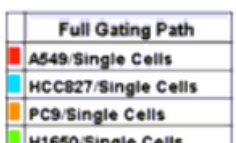

H1650/single Cells

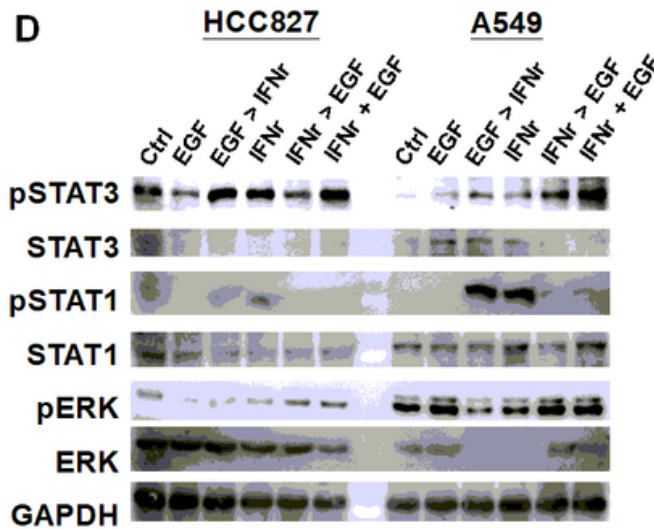

口 ctri

ㅁ EGF (1.5h)

HVEM

ㅁ EGF $(2 \mathrm{~h}) \rightarrow \operatorname{IFN\gamma }$ (1.5h) ㅁ IFNy (1.5h)

口 IFN $\gamma(2 h) \rightarrow$ EGF (1.5h)

EGF + IFN $\gamma(1.5 \mathrm{~h})$

Figure 3 
A

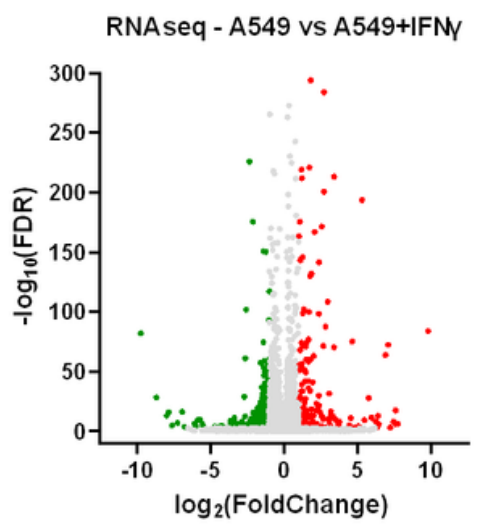

- Up: 173 (Fold change $\geq 2$, FDR $\leq 0.001$ )

- Down: 322 (Fold change $\leq-2$, FDR $\leq 0.001$ )
B

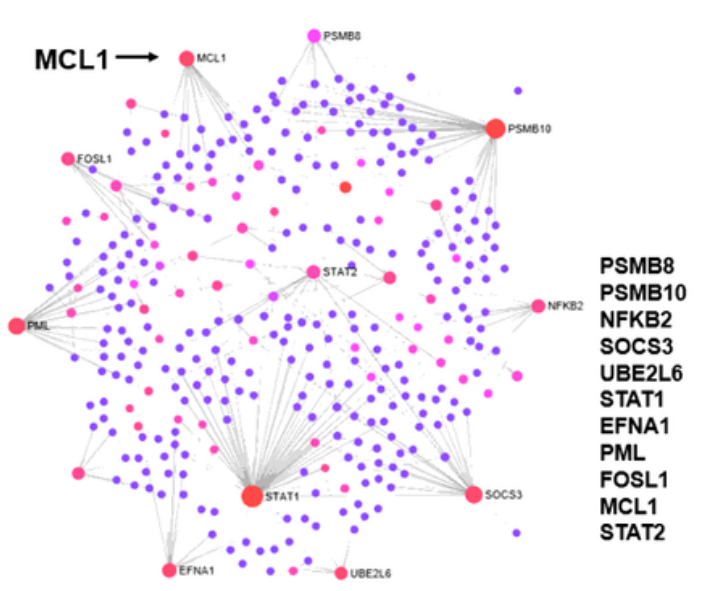

C

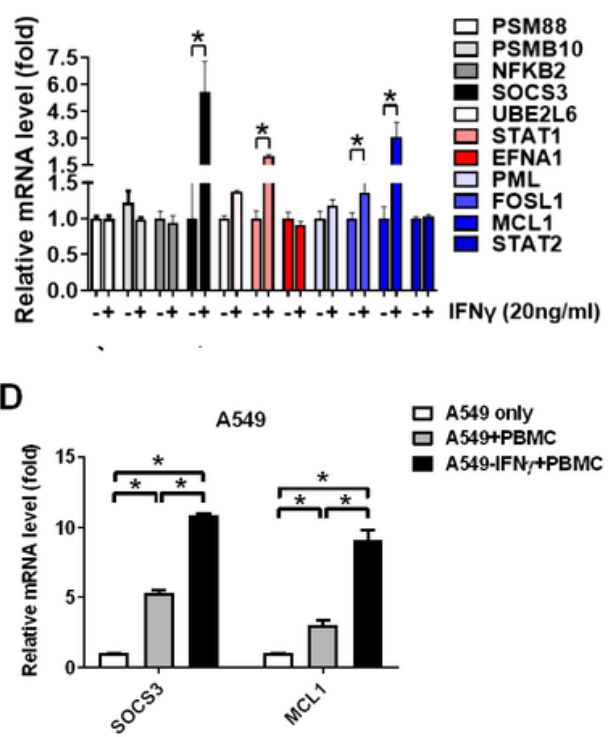

E
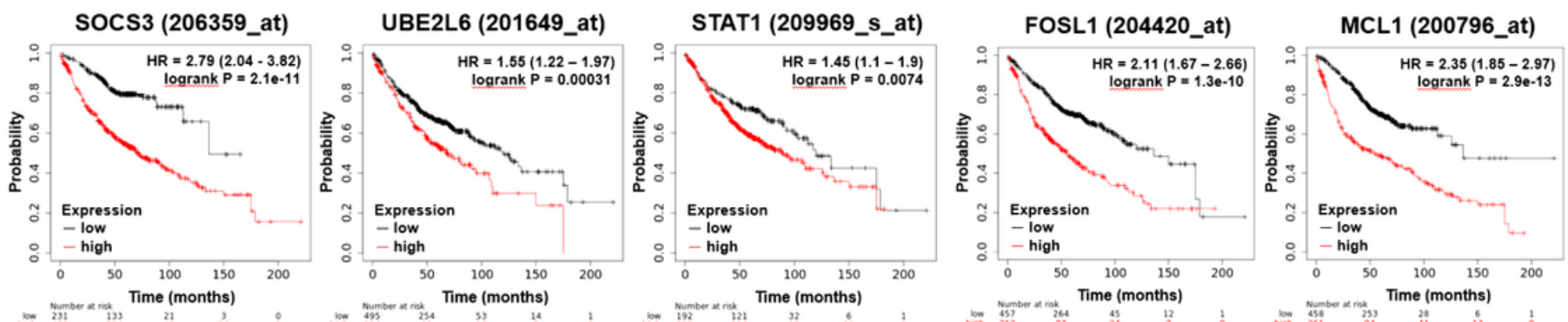

F
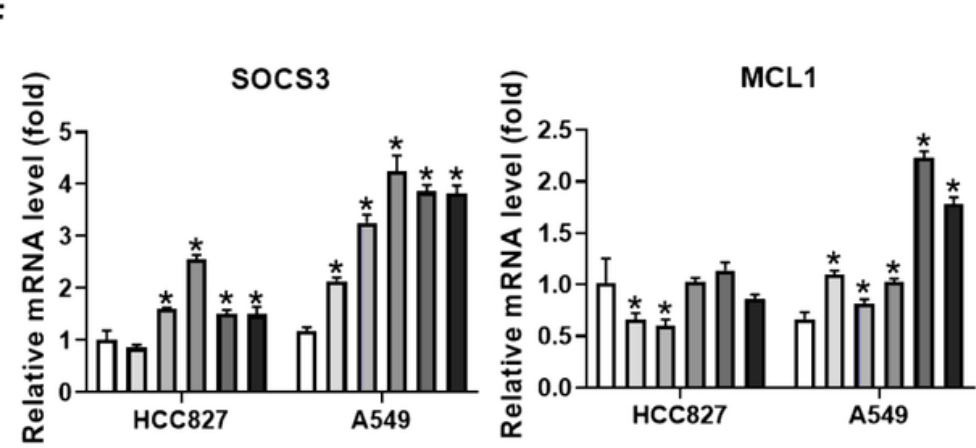

ㅁ Ctri

므 EGF (1.5h)

$\square$ EGF (2h) $\rightarrow$ IFNy (1.5h)

G

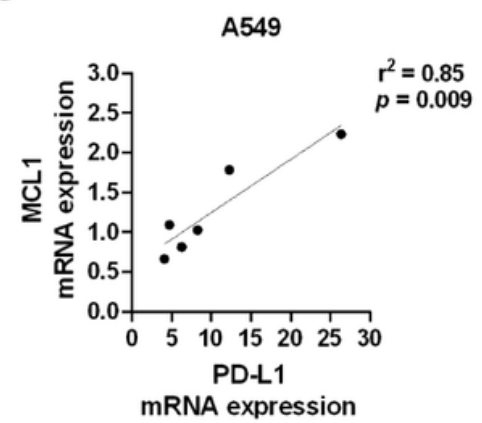

Figure 4 
A

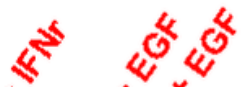

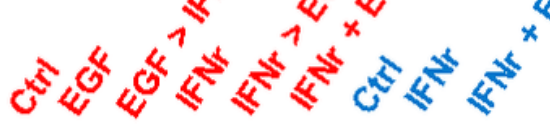

PSTAT3
STAT3
PSTAT1
STAT1 -
PERK =- = = =
ERK - -

GAPDH

B

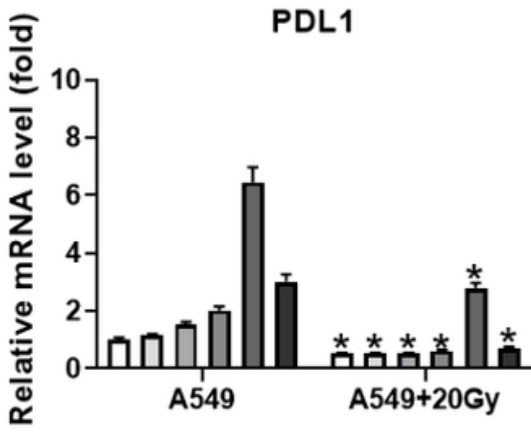

C

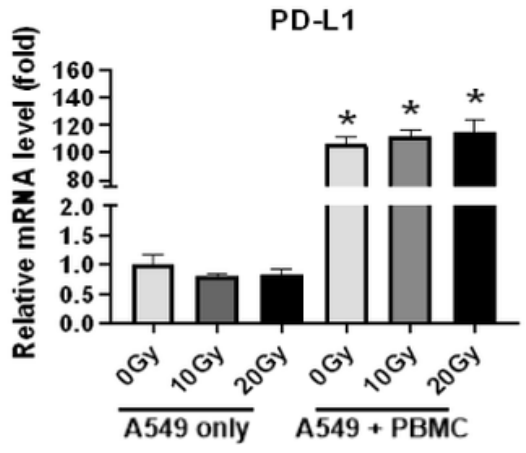

Figure 5
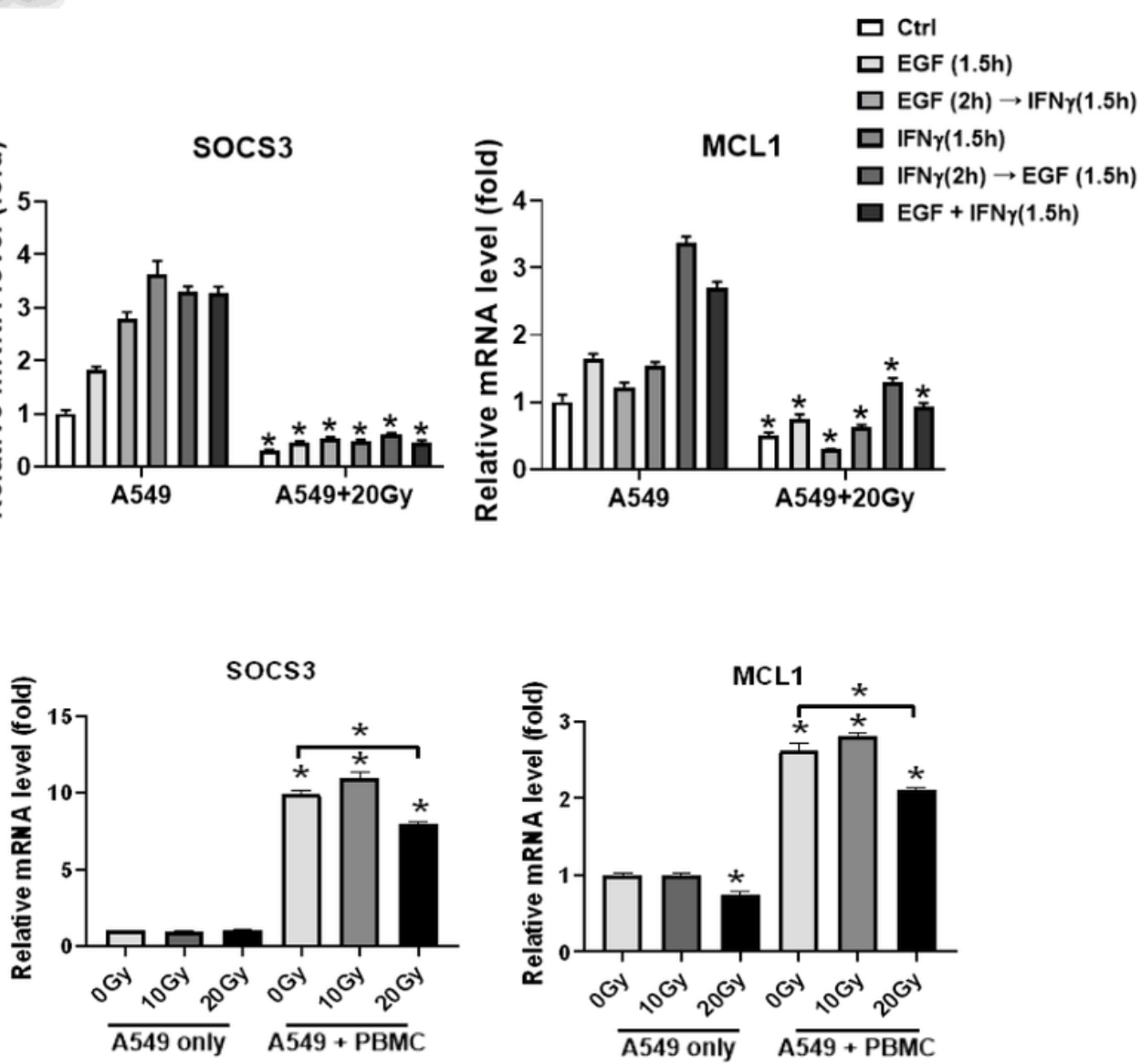

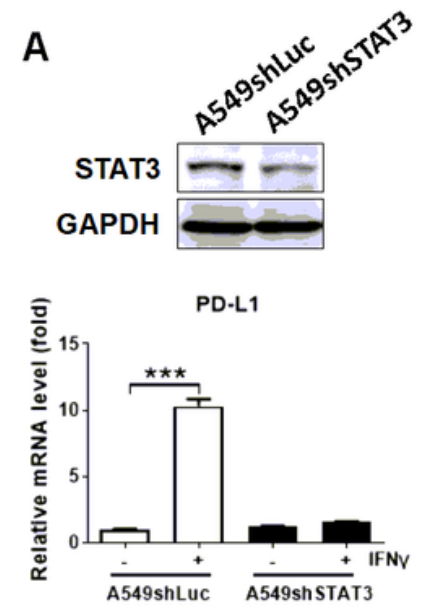

D

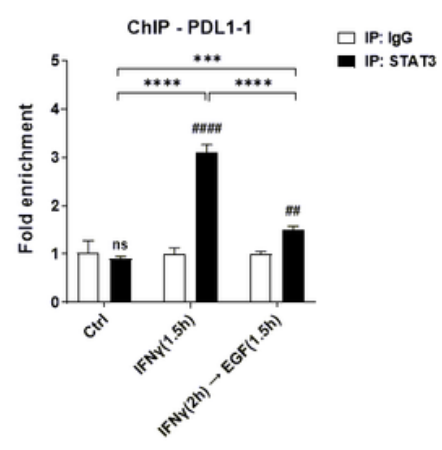

F

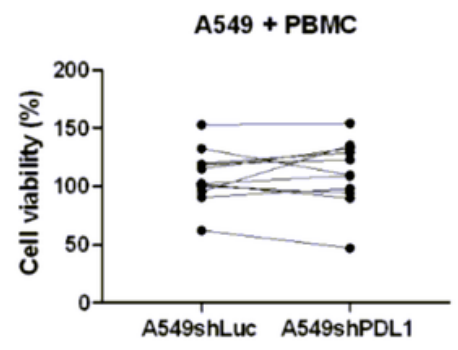

A549 + PBMC

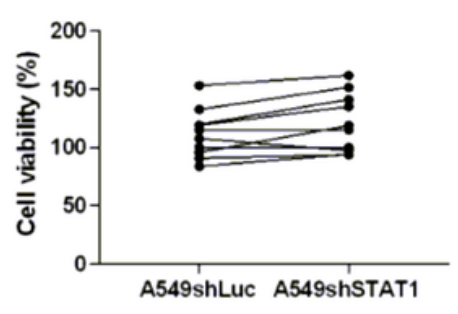

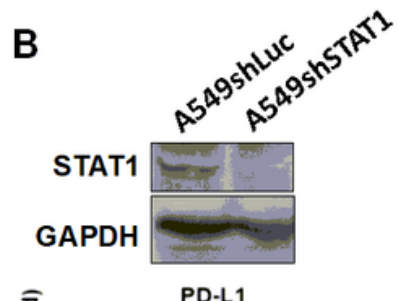
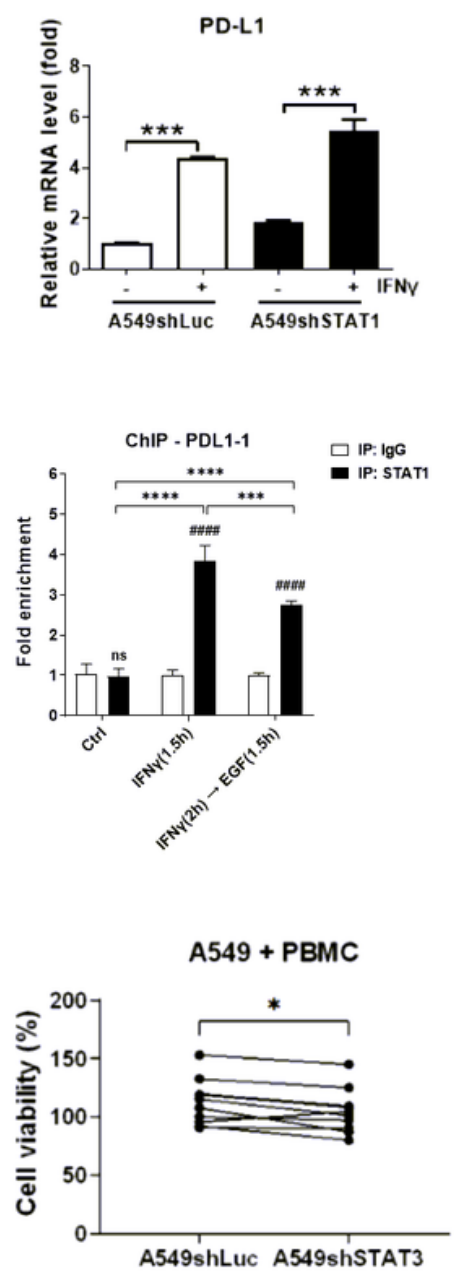

A549 + PBMC

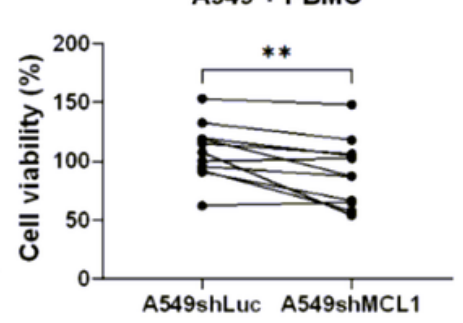

C
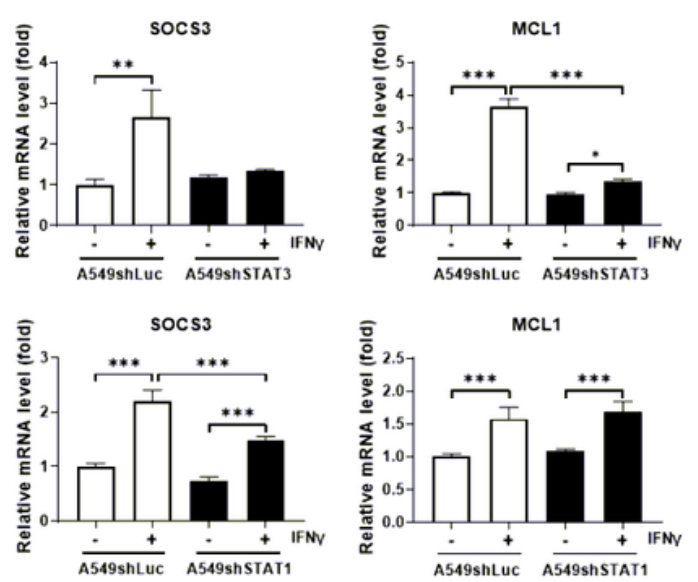

E
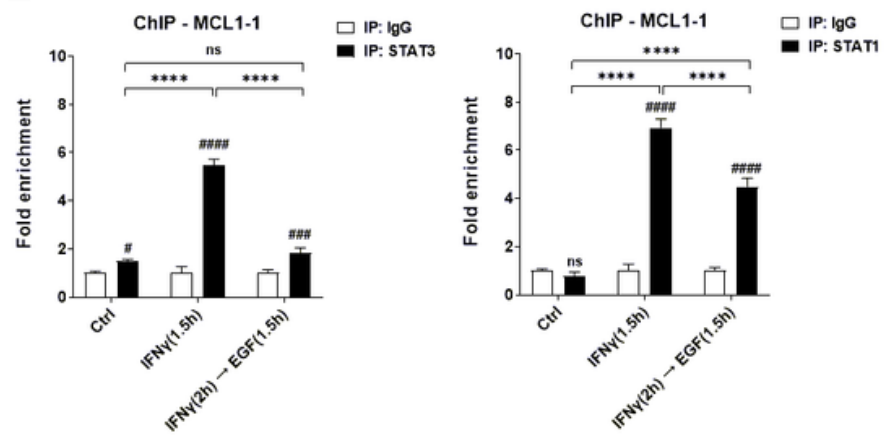

G
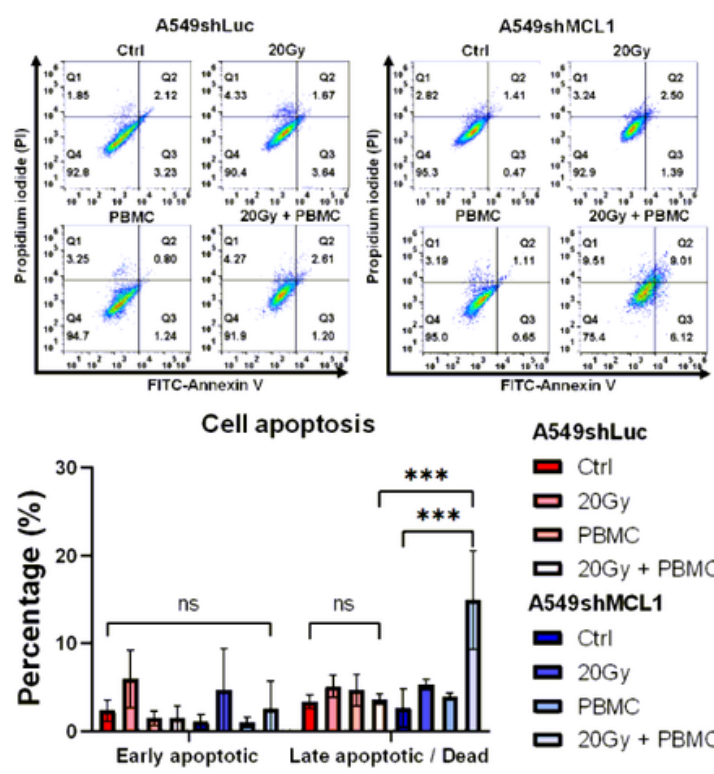

A549shLuc

口 Ctrl

口 20Gy

口 $\mathrm{PBMC}$

口 $20 \mathrm{~Gy}+\mathrm{PBMC}$

A549shMCL1

a Ctrl

口 20Gy

口 PBMC

口 20Gy + PBMC

Figure 6 


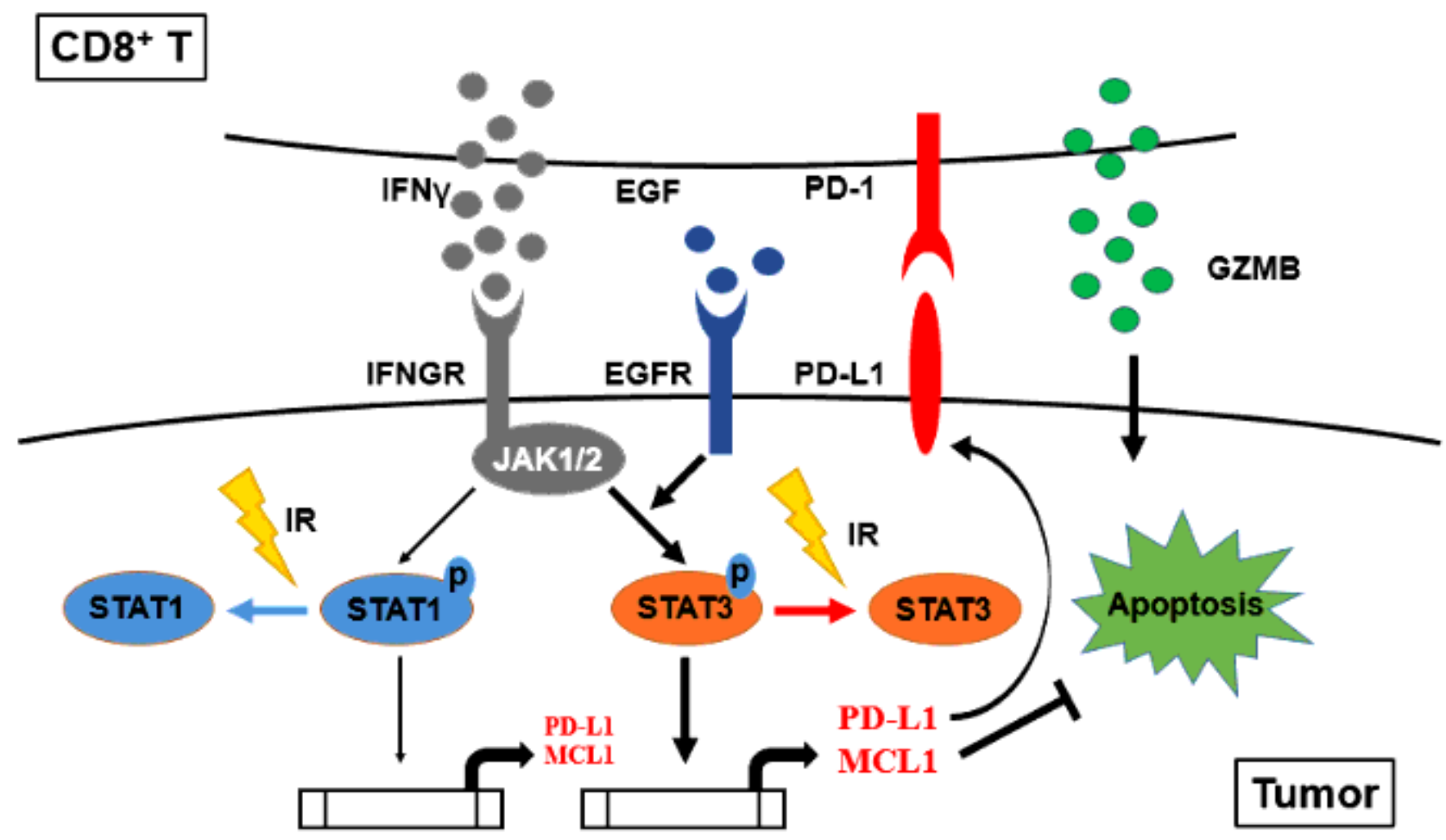

Figure 7

\section{Supplementary Files}

This is a list of supplementary files associated with this preprint. Click to download.

- TableS3.RNAseqA549IFNr.xlsx 